Prepared in cooperation with the Virginia Department of Transportation

\title{
Methods and Equations for Estimating Peak Streamflow Per Square Mille in Virginia's Urban Basins
}

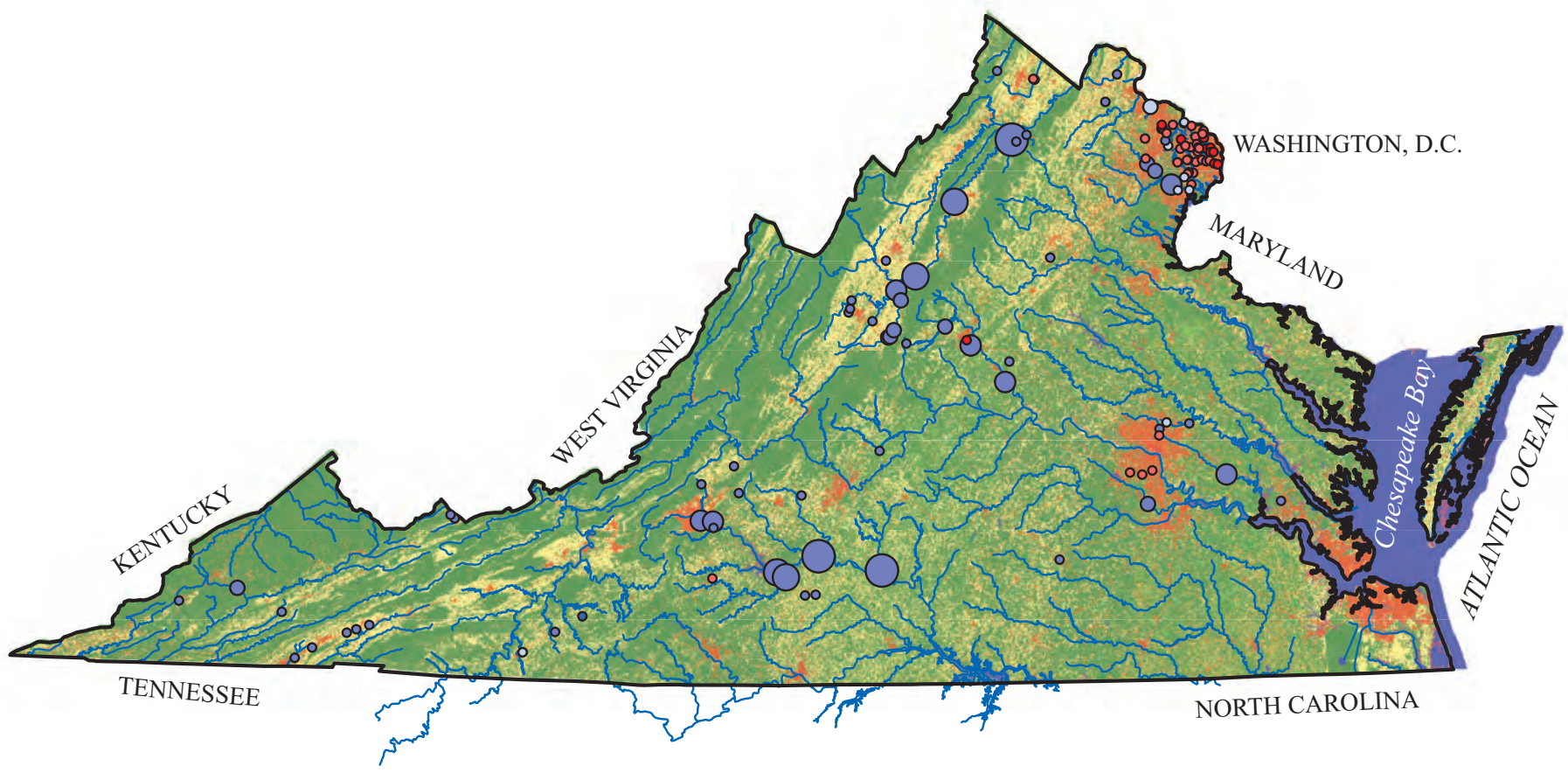

Scientific Investigations Report 2014-5090

U.S. Department of the Interior U.S. Geological Survey 
Cover. Map showing selected urban peak-flow study sites used to develop response surface models and estimating equations. Taken from figure 1 (p. 4). 


\section{Methods and Equations for Estimating Peak Streamflow Per Square Mile in Virginia's Urban Basins}

By Samuel H. Austin

Prepared in cooperation with the Virginia Department of Transportation

Scientific Investigations Report 2014-5090 


\title{
U.S. Department of the Interior SALLY JEWELL, Secretary
}

\section{U.S. Geological Survey Suzette M. Kimball, Acting Director}

\author{
U.S. Geological Survey, Reston, Virginia: 2014
}

For more information on the USGS - the Federal source for science about the Earth, its natural and living resources, natural hazards, and the environment, visit http://www.usgs.gov or call 1-888-ASK-USGS.

For an overview of USGS information products, including maps, imagery, and publications, visit http://www.usgs.gov/pubprod

To order this and other USGS information products, visit http://store.usgs.gov

Any use of trade, firm, or product names is for descriptive purposes only and does not imply endorsement by the U.S. Government.

Although this information product, for the most part, is in the public domain, it also may contain copyrighted materials as noted in the text. Permission to reproduce copyrighted items must be secured from the copyright owner.

Suggested citation:

Austin, S.H., 2014, Methods and equations for estimating peak streamflow per square mile in Virginia's urban basins: U.S. Geological Survey Scientific Investigations Report 2014-5090, 25 p., http://dx.doi.org/10.3133/sir20145090.

ISSN 2328-0328 (online)

ISSN 2328-031X (print)

ISBN 978-1-4113-3810-4 


\section{Acknowledgments}

The author thanks the Virginia Department of Transportation, whose continued collaboration and assistance made this report possible. George E. Harlow, Jr. of the U.S. Geological Survey is thanked for his advice, review, and editing of this report, and the author appreciates Jennifer Krstolic and Brian A. Hasty of the U.S. Geological Survey for developing a map for this report. 


\section{Contents}

Abstract
Introduction
Purpose and Scope
Characteristics of Streamflow in Urban Basins
Why Predict Peak Flows in Urban Areas?
Study Objectives
Analytical Approach
Site Selection
Data Evaluation
$\quad$ Model Development
Model Verification and Diagnostics Limitations
Urban Peak Flow Per Square Mile Estimates
Examples of Applying the Equations
Example 1
Example 2

\section{Figures}

1. Map showing selected urban peak-flow study sites used to develop response surface models and estimating equations.

Graphs showing:

2. Summary statistics and frequency distributions of response surface model explanatory variables

3. Examples of regressions prepared during initial tests of bivariate relations for $0.995,0.50$, and 0.10 urban peak-flow probability categories, showing urban basin peak flow per square mile as explained by $\log _{10}$-basin drainage area

4. Example leverage plots showing significant explanatory power, insignificant explanatory power and, evidence of collinearity.

5. Plots for the 0.8 model of urban peak flow per square mile showing actualby-predicted values, drainage area explanatory power, and urban area explanatory power.

6. How to read three-dimensional response surface model plots.

7. Urban peak flow per square mile response surface model for 0.995 annual exceedance probability streamflow in Virginia.

8. Urban peak flow per square mile response surface model for 0.99 annual exceedance probability streamflow in Virginia 
9. Urban peak flow per square mile response surface model for 0.95 annual

exceedance probability streamflow in Virginia...

10. Urban peak flow per square mile response surface model for 0.9 annual

exceedance probability streamflow in Virginia

11. Urban peak flow per square mile response surface model for 0.8 annual exceedance probability streamflow in Virginia.

12. Urban peak flow per square mile response surface model for 0.67 annual exceedance probability streamflow in Virginia

13. Urban peak flow per square mile response surface model for 0.5 annual exceedance probability streamflow in Virginia

14. Urban peak flow per square mile response surface model for 0.43 annual exceedance probability streamflow in Virginia.

15. Urban peak flow per square mile response surface model for 0.2 annual

exceedance probability streamflow in Virginia.

16. Urban peak flow per square mile response surface model for 0.1 annual

exceedance probability streamflow in Virginia.

17. Urban peak flow per square mile response surface model for 0.04 annual exceedance probability streamflow in Virginia.

18. Urban peak flow per square mile response surface model for 0.02 annual exceedance probability streamflow in Virginia.

19. Urban peak flow per square mile response surface model for 0.01 annual exceedance probability streamflow in Virginia.

20. Urban peak flow per square mile response surface model for 0.005 annual exceedance probability streamflow in Virginia.

21. Urban peak flow per square mile response surface model for 0.002 annual

exceedance probability streamflow in Virginia.

22. Leverage plots indicating statistically significant cross-product effects in response surface models for $0.995,0.50$ and 0.10 urban peak flow probability categories, and insignificant cross-product effects in response surface models for $0.01,0.005$, and 0.002 urban peak-flow probability categories

23. Urban peak flow per square mile actual-by-predicted plot for 0.995 annual exceedance probability streamflow in Virginia.

24. Urban peak flow per square mile actual-by-predicted plot for 0.99 annual exceedance probability streamflow in Virginia.

25. Urban peak flow per square mile actual-by-predicted plot for 0.95 annual exceedance probability streamflow in Virginia.

26. Urban peak flow per square mile actual-by-predicted plot for 0.9 annual exceedance probability streamflow in Virginia.

27. Urban peak flow per square mile actual-by-predicted plot for 0.8 annual exceedance probability streamflow in Virginia....

28. Urban peak flow per square mile actual-by-predicted plot for 0.67 annual

exceedance probability streamflow in Virginia.

29. Urban peak flow per square mile actual-by-predicted plot for 0.5 annual

exceedance probability streamflow in Virginia.

30. Urban peak flow per square mile actual-by-predicted plot for 0.43 annual exceedance probability streamflow in Virginia.

31. Urban peak flow per square mile actual-by-predicted plot for 0.2 annual exceedance probability streamflow in Virginia. 
32. Urban peak flow per square mile actual-by-predicted plot for 0.1 annual exceedance probability streamflow in Virginia

33. Urban peak flow per square mile actual-by-predicted plot for 0.04 annual exceedance probability streamflow in Virginia

34. Urban peak flow per square mile actual-by-predicted plot for 0.02 annual exceedance probability streamflow in Virginia.

35. Urban peak flow per square mile actual-by-predicted plot for 0.01 annual exceedance probability streamflow in Virginia.

36. Urban peak flow per square mile actual-by-predicted plot for 0.005 annual exceedance probability streamflow in Virginia.

37. Urban peak flow per square mile actual-by-predicted plot for 0.002 annual exceedance probability streamflow in Virginia

\section{Tables}

1. Drainage basins used to estimate Virginia urban peak-flow discharge per square mile

2. Parameters for regression equations used for estimating Virginia urban peak-flow discharge per square mile

3. Regression equation prediction expressions for estimating Virginia urban peak-flow discharge per square mile

\section{Equations}

1. Form of a standard least squares regression equation ....................................................6

2 Form of each response surface model prediction expression .........................................6 


\section{Conversion Factors}

\begin{tabular}{|c|c|c|}
\hline Multiply & By & To obtain \\
\hline \multicolumn{3}{|c|}{ Length } \\
\hline foot $(\mathrm{ft})$ & 0.3048 & meter $(\mathrm{m})$ \\
\hline mile (mi) & 1.609 & kilometer $(\mathrm{km})$ \\
\hline \multicolumn{3}{|c|}{ Area } \\
\hline acre & 0.4047 & hectare (ha) \\
\hline square foot $\left(\mathrm{ft}^{2}\right)$ & 0.09290 & square meter $\left(\mathrm{m}^{2}\right)$ \\
\hline square mile $\left(\mathrm{mi}^{2}\right)$ & 259.0 & hectare (ha) \\
\hline \multicolumn{3}{|c|}{ Volume } \\
\hline gallon (gal) & 0.003785 & cubic meter $\left(\mathrm{m}^{3}\right)$ \\
\hline cubic foot $\left(\mathrm{ft}^{3}\right)$ & 0.02832 & cubic meter $\left(\mathrm{m}^{3}\right)$ \\
\hline acre-foot (acre-ft) & 1,233 & cubic meter $\left(\mathrm{m}^{3}\right)$ \\
\hline \multicolumn{3}{|c|}{ Flow rate } \\
\hline acre-foot per day (acre-ft/d) & 0.01427 & cubic meter per second $\left(\mathrm{m}^{3} / \mathrm{s}\right)$ \\
\hline foot per second (ft/s) & 0.3048 & meter per second $(\mathrm{m} / \mathrm{s})$ \\
\hline cubic foot per second $\left(\mathrm{ft}^{3} / \mathrm{s}\right)$ & 0.02832 & cubic meter per second $\left(\mathrm{m}^{3} / \mathrm{s}\right)$ \\
\hline \multicolumn{3}{|c|}{ Hydraulic gradient } \\
\hline foot per mile (ft/mi) & 0.1894 & meter per kilometer $(\mathrm{m} / \mathrm{km})$ \\
\hline
\end{tabular}

Vertical coordinate information is referenced to the North American Vertical Datum of 1988 (NAVD 88).

Horizontal coordinate information is referenced to the North American Datum of 1983 (NAD 83).

Altitude, as used in this report, refers to distance above the vertical datum. 



\title{
Methods and Equations for Estimating Peak Streamflow Per Square Mile in Virginia's Urban Basins
}

\author{
By Samuel H. Austin
}

\begin{abstract}
Models are presented that describe Virginia urban area annual peak streamflow per square mile based on basin percent urban area and basin drainage area. Equations are provided to estimate Virginia urban peak flow per square mile of basin drainage area in each of the following annual exceedance probability categories: $0.995,0.99,0.95,0.9,0.8,0.67$, $0.5,0.43,0.2,0.1,0.04,0.02,0.01,0.005$, and 0.002 (recurrence intervals of $1.005,1.01,1.05,1.11,1.25,1.49,2.0,2.3$, $5,10,25,50,100,200$, and 500 years, respectively). Equations apply to Virginia drainage basins ranging in size from no less than $1.2 \mathrm{mi}^{2}$ to no more than $2,400 \mathrm{mi}^{2}$ containing at least 10 percent urban area, and not more than 96 percent urban area. A total of 115 Virginia drainage basins were analyzed. Actual-by-predicted plots and leverage plots for response variables and explanatory variables in each peak-flow annual exceedance probability category indicate robust model fits and significant explanatory power. Equations for 8 of 15 urban peak-flow response surface models yield R-square values greater than 0.8 . Relations identified in statistical models, describing significant increases in urban peak stream discharges as basin urban area increases, affirm empirical relations reported in past studies of change in stream discharge, lag times, and physical streamflow processes, most notably those detailed for urban areas in northern Virginia.
\end{abstract}

\section{Introduction}

Anticipating high-flow conditions in Virginia's urban streams is essential to sound management of water resources and associated riparian and watershed ecosystems. Reliable predictions of urban peak flows inform planning and design, improving management of urban basins. Understanding peak flows specific to urban basins and their relation to land-use changes over time allows anticipation of shifts in peak-flow magnitude and frequency. This knowledge can improve the design of hydraulic structures and the management of riparian systems and the ecology associated with urban landscapes. Urban peak-flow estimates also provide a basis for analysis of future streamflow response to changes in ecosystem and climate.
The U.S. Geological Survey, in cooperation with the Virginia Department of Transportation, developed statistical models and equations to predict flow response in Virginia's urban streams. Basin drainage area and basin percent urban area were used to identify and predict peak urban streamflow, which aids in the understanding of water flows and the environmental health of urban basins and their associated ecosystems.

\section{Purpose and Scope}

This report presents results of a study conducted to (1) develop a set of response surface models that describe Virginia urban area peak flow based on changes in basin percent urban area and basin drainage area; (2) develop a series of equations that may be used to accurately estimate Virginia urban peak streamflow per square mile of basin drainage area in the following annual exceedance probability (AEP) categories: $0.995,0.99,0.95,0.9,0.8,0.67,0.5,0.43,0.2,0.1,0.04$, $0.02,0.01,0.005$, and 0.002 (recurrence intervals of 1.005 , $1.01,1.05,1.11,1.25,1.49,2.0,2.3,5,10,25,50,100,200$, and 500 years, respectively), and (3) demonstrate how to use these equations to estimate urban peak streamflow per square mile of basin drainage area. Measurements of basin percent urban area and basin square mile drainage area are used as explanatory variables in 15 response surface models. Measurements and models are evaluated and iteratively refined to prepare a set of 15 regression equations. Examples are provided describing equation applicability and use.

\section{Characteristics of Streamflow in Urban Basins}

Streams in urban areas serve important functions. They are sources of water withdrawals for industrial, agricultural, and domestic uses, and they are essential to the maintenance and functioning of the physical and ecological processes associated with the surrounding urban landscape and within the larger basin. Streamflow through urban streams maintains channel morphology, channel functions, and movement of natural sediments. This transport of rainfall and runoff also helps to prevent flooding. These same flows provide habitat and food sources for aquatic organisms, as well as transportation 
corridors and water sources essential to aquatic organisms and terrestrial plants and animals.

The effects of urbanization upon stream systems are significant. In their book "Water in Environmental Planning," Dunne and Leopold (1978) describe the changes to stream systems that occur as basin urban area increases. Changes in runoff processes result from covering parts of the basin with impervious roofs, sidewalks, roadways, and parking lots. The infiltration capacity of these areas drops to zero, and the volume and rate of overland flow is increased. Because urban gutters, drains, and storm sewers are laid out in a manner meant to convey runoff rapidly to stream channels, and natural channels are often straightened, deepened, or lined with concrete to make them hydraulically smoother, channel efficiencies are increased and flood waters are transmitted downstream more quickly and with less storage in the channel than would be available in a natural stream system. Stormwaters accumulate downstream more quickly than in natural stream systems, producing higher flood peaks. Increased water velocities in stream channels decrease the lag between rainfall and runoff. Decreased lag times ensure that peak-flow rates must increase, even if total water volumes remain constant. In fact, total water volumes actually increase because net infiltration of precipitation is reduced as a consequence of impervious surfaces. This increase in total water volume drives flood peaks even higher than they would be if water volumes remained constant.

The increased peak flows in urbanizing basins lead to significant consequences that must be identified and anticipated by infrastructure planners, designers, and managers. Overbank flooding, as peak flows exceed the capacity of natural channels, may cause damage to structures or landscapes, or may disrupt traffic. Areas near streams may suffer erosion and reduced property values. Culverts and bridges may be overtaxed and may eventually fail if not designed with sufficient capacity to handle larger water flows. Because water conveyed during increased peak flows is not available to infiltrate and recharge groundwater supplies, low flows during dry months are often reduced, resulting in degraded water quality. Less water is available for withdrawal and use, and the efficacy of stream processes, such as transfer of sediments, is limited.

\section{Why Predict Peak Flows in Urban Areas?}

Predictions of urban streamflows allow us to better protect against floods, anticipate water availability during critical periods, and facilitate improved planning and management of water resources. The benefits of accurate flow predictions include (1) extended lead-times for designing and building urban infrastructure and flow control structures, (2) improved knowledge and prediction of high flows during storms, (3) anticipation of future high flows as functions of change in urban land area, regional and local precipitation, water withdrawals, land-use management, and climate.

\section{Previous Studies}

Previous studies have investigated the effects of urban development on streamflows in Virginia. Anderson (1968 and 1970) prepared empirical relations projecting the effects of urban development on floods in northern Virginia. Dunne and Leopold (1978) described generalized runoff processes in urban areas and conditions associated with urban runoff. Focazio and others (1993) described the effects of wetlands on water quality downstream from an urbanized area in Virginia. Leopold (1968) summarized the general effects of urbanization on hydrologic factors. Rice (2000) identified the effects of urban sprawl on the water resources of northern Virginia. With the exception of Dunne and Leopold's generalized description of urban runoff conditions, each of these studies focused on aspects of urban streamflow at relatively local scales for areas composed of several basins or several counties.

\section{Study Objectives}

This study estimates peak streamflows per square mile associated with urban basins in Virginia. Urban response surface models and equations are developed from analysis of Virginia peak-flows and basin data, specifically basin percent urban area and basin drainage area, published by Austin and others (2011b). A set of response surface models that describe Virginia urban area peak streamflow per square mile of basin drainage area is presented along with a set of equations that may be used to accurately estimate Virginia urban peak streamflow per square mile of basin drainage area. Examples are provided demonstrating how to use the equations, with the intent of facilitating awareness, planning, and management of streams within Virginia's urbanizing basins.

\section{Analytical Approach}

Response surface models and regression equations were developed for each peak-flow annual exceedance probability category to estimate urban peak streamflow per square mile from percentage of basin urban area and $\log _{10}$-transformed basin drainage area. Response surface models fit continuous parameters using the principle of least squares to describe a response (y) as a function of several explanatory (x) variables. A response surface was created illustrating the threedimensional nature of relations among the variables. Percent urban area and square mile drainage area were compiled for stream-gaging stations associated with published peakflow characteristics (Austin and others, 2011b; Hayes and Wiegand 2006; Homer and others, 2004). These urban-area and drainage-area data were evaluated. Provisional response surface models were prepared, evaluated, and modified. Final response surface models were developed using regression analysis. Final regression equations were prepared for use in 
estimating urban peak streamflow per square mile of drainage area. These response surface models and regression equations facilitate estimating peak flows in urban basins, simulating peak-flow effects of increasing or decreasing basin urban area, and simulating peak-flow response to rates of change in basin land use.

\section{Site Selection}

Study sites were identified and selected by using peakflow estimates and basin characteristics published in U.S. Geological Survey Scientific Investigations Report 2011-5144, "Peak-Flow Characteristics of Virginia Streams" (Austin and others 2011b). Tables 5 and 6 of "Peak-Flow Characteristics of Virginia Streams" list Virginia basin percent urban area, defined as the fraction of basin land area classified as urban area, and basin drainage area defined as the published values of surface drainage area for each basin in the study. Basin percent urban area values were prepared from land cover classification data (Homer and others, 2004). Land cover data from four land cover classes were combined to determine percent urban area. The four land cover classes are open space, low-intensity development, medium-intensity development, and high-intensity development, and range from areas where impervious surfaces account for less than 20 percent of total land cover to areas where impervious surfaces account for 80 to nearly 100 percent of total land cover (Homer and others, 2004). A ratio of land area occupied by the combined four urban land cover classes to the total basin drainage area was calculated to yield basin percent urban area. Basin drainage area values previously published by Hayes and Wiegand (2006) were used in the analysis. These values are also available as basin characteristics listed in table 6 of Austin and others (2011b). Krstolic (2006) provides the digital boundaries associated with these basins.

Site selection began with more than 3,500 sites in Virginia for which records of water discharge measurements have been collected. Of these, 3,226 may be identified as sites with urban land cover associated with at least 1 percent of the upstream basin, and 2,073 may be identified as sites for which urban land cover is associated with at least 5 percent of the upstream basin. There are 1,068 sites that may be identified as having urban land cover associated with at least 10 percent of the upstream basin. Exploratory analyses undertaken using the three datasets associated with 1 percent, 5 percent, and 10 percent basin urban land cover identified meaningful relations between urban peak flow per square mile and basin percent urban area when at least 10 percent of basin drainage area is occupied by urban land. The dataset containing 1,068 sites for which urban land cover is associated with at least 10 percent of each upstream basin was thus selected for additional analysis. Interestingly, the 10 percent urban land cover minimum threshold of meaningful influence on urban peak flows, though identified independently, coincides with urban land cover minimum thresholds of meaningful influence at or near
10 percent as reported in other studies of urban peak flows (Booth and Jackson, 1997; Klein, 1979; Landers and others, 2007; Mallin and others, 2000). Of the 1,068 sites for which urban land cover is associated with at least 10 percent of each upstream basin, 115 sites were identified as also having records of continuous stream-gaging measurements that were extensively evaluated and used to compute peak-flow statistics from which peak-flow characteristics were determined and published in Austin and others (2011b). These 115 sites were selected for use in this study.

Selection of these 115 sites constrained urban response surface models to basin urban area explanatory variable input values between 10 percent and 96 percent. The 115 selected study sites, for which urban land cover is associated with at least 10 percent of the upstream basin area, are listed in table 1 and shown in figure 1 .

\section{Data Evaluation}

The selected urban peak-flow study sites are located throughout Virginia. Basin drainage area associated with the 115 study sites ranges from 0.07 square mile $\left(\mathrm{mi}^{2}\right)$ to $2,404 \mathrm{mi}^{2}$. The mean basin drainage area is $143.6 \mathrm{mi}^{2}$, and the median basin drainage area is $8.26 \mathrm{mi}^{2}$. Basin drainage area data were $\log _{10}$-transformed to facilitate use as an explanatory variable as suggested by Tukey's bulging rule (Mosteller and Tukey, 1977). The $\log _{10}$-transformed distribution of basin drainage area values for the selected study sites is normally distributed, with a minimum value of -1.16 and a maximum value of 3.38. The mean $\log _{10}$-transformed basin drainage area is 1.08 , and the median $\log _{10}$-transformed basin drainage area is 0.92 . Basin percent urban area associated with the 115 study sites ranges from 10 percent to 96 percent. The mean basin percent urban area is 39.01 percent, and the median basin percent urban area is 25.75 percent (fig. 2).

\section{Data Analysis}

Data analysis began with thorough, iterative evaluation and screening of relations among response variables and explanatory variables. First, percent urban area, basin drainage area, and mathematical transformations of each were screened for applicability and explanatory power. Then, bivariate relations were explored. Single explanatory variables were tested to discover their potential efficacy in determining a response. Bivariate relations were tested in each of 15 response categories: urban basin peak flow per square mile for annual exceedance probabilities of $0.995,0.99,0.95,0.9,0.8,0.67$, $0.5,0.43,0.2,0.1,0.04,0.02,0.01,0.005$, and 0.002 (recurrence intervals of $1.005,1.01,1.05,1.11,1.25,1.49,2.0,2.3$, $5,10,25,50,100,200$, and 500 years, respectively). From these initial iterative screenings and tests of bivariate relations, it soon became apparent that (1) basin percent urban area and (2) $\log _{10}$-basin drainage area are each potentially useful predictors of urban basin peak flow per square mile. 


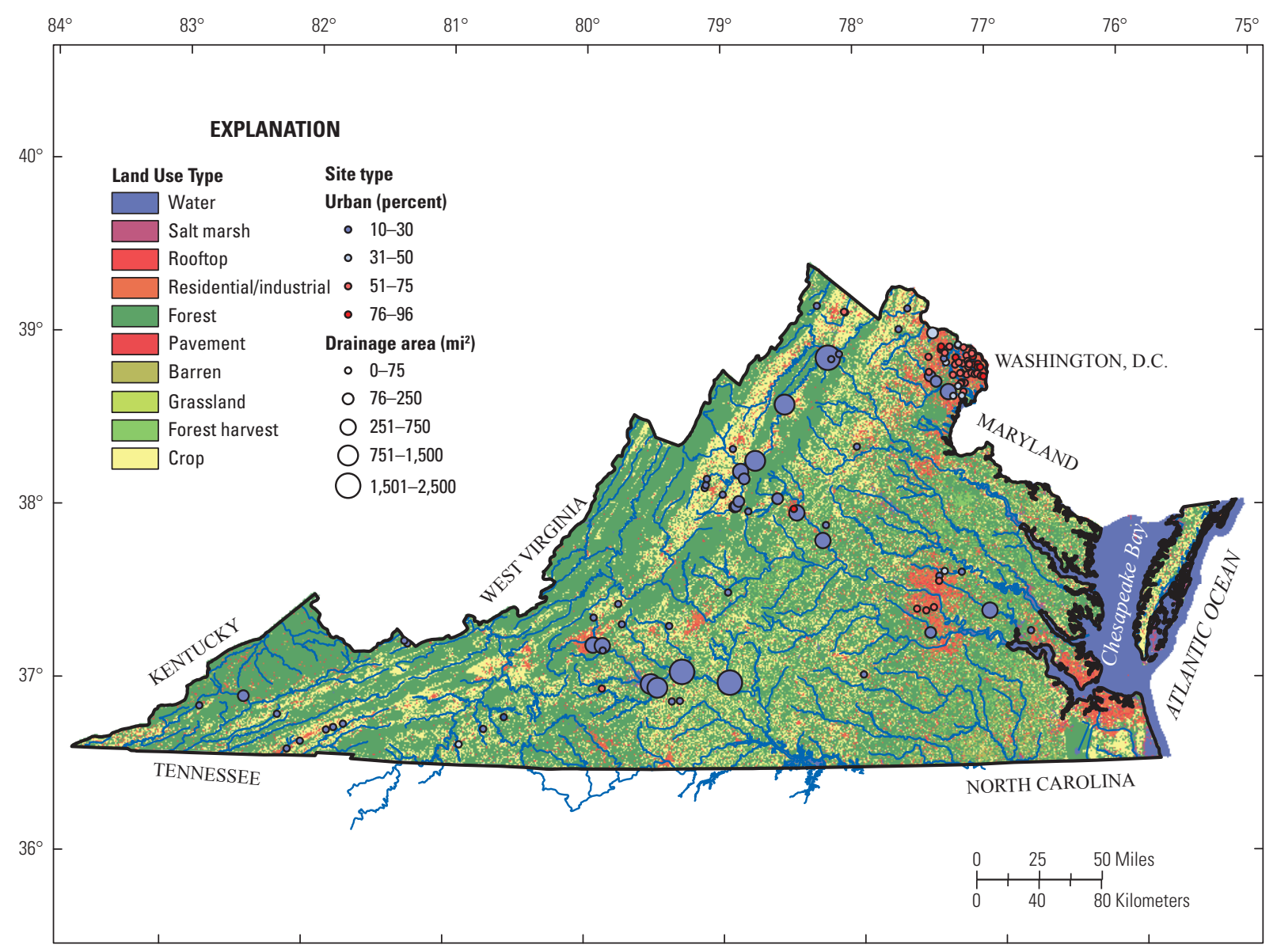

Base from U.S. Geological Survey Digital Line Graph, 1:2,000,000 (1987) Projection: Albers Equal Area, NAD 83,

Land cover: Fry and others, 2011,

Completion of the 2006 National Land Cover Database for the Conterminous United States:

Photogrammetric Engineering and Remote Sensing, v. 70, no. 9, p. 858-864.

Drainage area: Hayes, D.C. and Wiegand, U. 2006,

Drainage Areas of Selected Streams of Virginia: U.S. Geological Survey

Open-File Report 2006-1308, p. 51.

Figure 1. Selected urban peak-flow study sites used to develop response surface models and estimating equations. For each of the 115 sites, urban land cover is associated with at least 10 percent of the upstream basin. Each dot represents one study site. Dot color indicates the percentage of urban area in the basin. Dot size indicates relative basin drainage area, in square miles. 


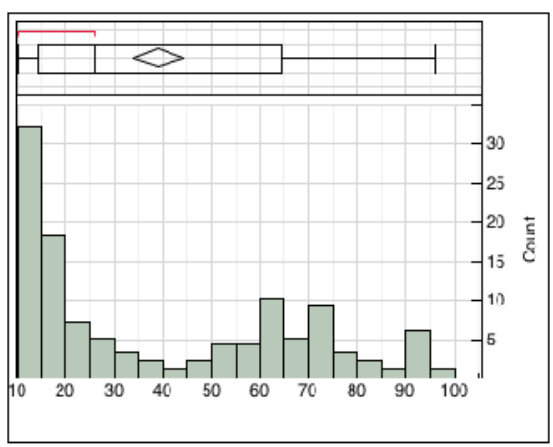

(a) Basin percent urban area

$\begin{array}{ccc}\begin{array}{c}\text { Quantiles } \\ 100.0 \%\end{array} & \text { maximum } & \\ 99.5 \% & & 95.96 \\ 97.5 \% & & 95.96 \\ 90.0 \% & & 78.11 \\ 75.0 \% & \text { quartile } & 64.51 \\ 50.0 \% & \text { median } & 25.75 \\ 25.0 \% & \text { quartile } & 14.42 \\ 10.0 \% & & 11.12 \\ 2.5 \% & & 10.14 \\ 0.5 \% & & 10.01 \\ 0 \% & \text { minimum } & 10.01\end{array}$

Summary Statistics

$\begin{array}{lr}\text { Mean } & 39.01 \\ \text { Std Dev } & 27.62 \\ \text { Std Err Mean } & 2.58 \\ \text { Upper 95\% Mean } & 44.11 \\ \text { Lower 95\% Mean } & 33.90 \\ \text { N } & 115\end{array}$

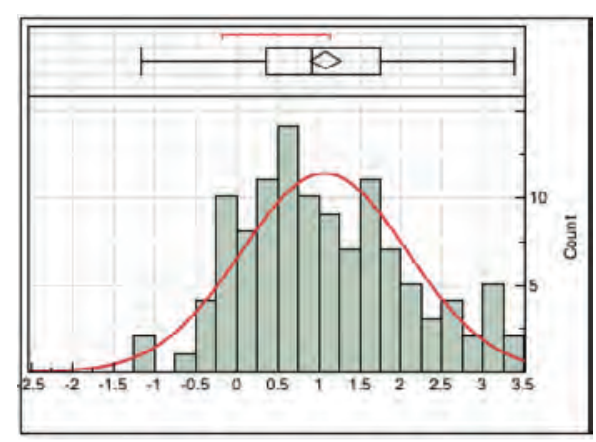

(b) $\log _{10}$-basin drainage area $\left(\mathrm{mi}^{2}\right)$

$\begin{array}{rlr}\begin{array}{c}\text { Quantiles } \\ 100.0 \%\end{array} & \text { maximum } & 3.38 \\ 99.5 \% & & 3.38 \\ 97.5 \% & & 3.22 \\ 90.0 \% & & 2.63 \\ 75.0 \% & \text { quartile } & 1.75 \\ 50.0 \% & \text { median } & 0.92 \\ 25.0 \% & \text { quartile } & 0.36 \\ 10.0 \% & & -0.17 \\ 2.5 \% & & -0.62 \\ 0.5 \% & & -1.16 \\ 0.0 \% & \text { minimum } & -1.16\end{array}$

\section{Summary Statistics}

Mean

Std Dev

Std Err Mean

Upper $95 \%$ Mean

Lower 95\% Mean

N

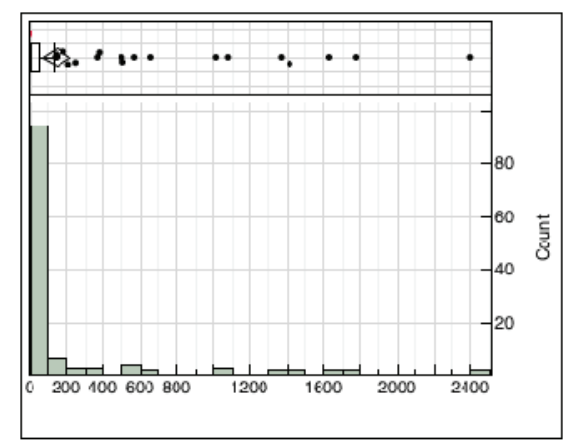

(c) Basin drainage area $\left(\mathrm{mi}^{2}\right)$

$\begin{array}{cll}\begin{array}{c}\text { Quantiles } \\ 100.0 \%\end{array} & \text { maximum } & 2,404 \\ 99.5 \% & & 2,404 \\ 97.5 \% & & 1,649 \\ 90.0 \% & & 431.7 \\ 75.0 \% & \text { quartile } & 55.81 \\ 50.0 \% & \text { median } & 8.26 \\ 25.0 \% & \text { quartile } & 2.28 \\ 10.0 \% & & 0.68 \\ 2.5 \% & & 0.25 \\ 0.5 \% & & 0.07 \\ 0 \% & \text { minimum } & 0.07\end{array}$

Summary Statistics

Mean $\quad 143.6$

Std Dev 388.6

Std Err Mean $\quad 36.24$

Upper 95\% Mean 215.4

Lower 95\% Mean $\quad 71.81$

$\mathrm{N} \quad 115$

Figure 2. Summary statistics and frequency distributions of response surface model explanatory variables: (a) basin percent urban area, and $(b) \log _{10}$-basin drainage area. Summary statistics and frequency distribution for $(c)$ non- $\log _{10}$-transformed basin drainage area are shown for comparison.

\section{Model Development}

Bivariate relations using linear regression, as shown in figure 3, were used to test potential explanatory variables including basin percent urban area, $\log _{10}$-basin drainage area, and basin area encompassing discrete ranges of percent impervious surface in the following categories: 0 percent impervious surface, 1 to 5 percent impervious surface, 6 to 10 percent impervious surface, 11 to 25 percent impervious surface, 26 to 50 percent impervious surface, 51 to 75 percent impervious surface, and 76 to 100 percent impervious surface. These tests clearly identified (1) overall basin percent urban area and (2) $\log _{10}$-basin drainage area as the most informative and potentially useful predictors of urban basin peak flow per square mile over the range of peak-flow response categories. These relations were further investigated. Preliminary models were developed by using standard least squares regression to predict urban basin peak flow per square mile in each response category by a combination of two explanatory variables, basin percent urban area and $\log _{10}$-basin drainage area. These regressions combining two explanatory variables for each response curve were used to develop response surface models.
Response surface models fit continuous parameters using the principle of least squares to describe a response (y), as a function of several explanatory $(\mathrm{x})$ variables. A response surface is created to illustrate and document the three-dimensional nature of relations between a single response variable - basin peak flow per square mile - and two explanatory variables - basin percent urban area and $\log _{10}$-basin drainage area. Response surface models follow the form of standard least squares regression (eq. 1). Cross-product effects in response surface models yield final equation prediction expressions (eq. 2). Each datapoint used in the fitting of a response surface model is an observation. The 115 study sites suggest the potential availability of 115 observations for each response surface model. There are instances when a meaningful response (y) value for a single study site is not determined for 1 of the 15 annual exceedance probability response categories used in response surface models. This is due to lack of sufficient data to describe a particular probability response for the single study site. In these instances, a response surface model is developed without the observation-probability response (y) value and associated explanatory $(\mathrm{x})$ values - particular to the single study site. Parameters for each regression equation are 

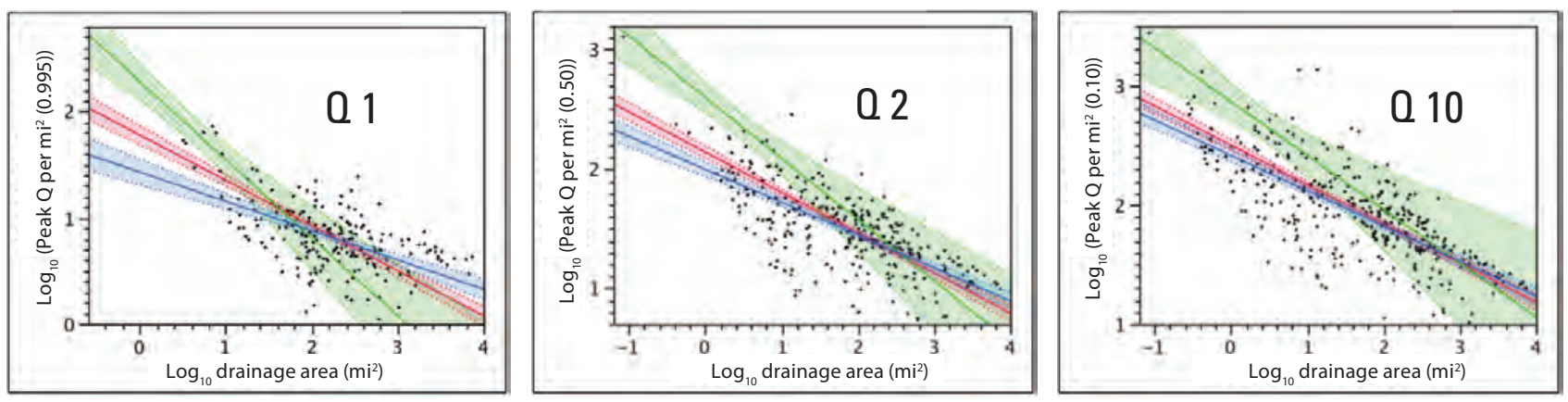

Figure 3. Examples of regressions prepared during initial tests of bivariate relations for $0.995,0.50$, and 0.10 urban peak-flow probability categories [recurrence intervals of 1 year (01), 2 years (02), and 10 years (010), respectively], showing urban basin peak flow per square mile as explained by $\log _{10}$-basin drainage area. Red lines and shading describe all basins, green lines and shading describe urban basins, blue lines and shading describe rural basins ( 0 denotes discharge).

listed in table 2. Regression equation prediction expressions for each response surface model, estimating Virginia urban peak flow per square mile, are listed in table 3 along with the number of observations used in each response surface model.

$$
y=\beta_{0}+\beta_{1} x_{1}+\beta_{2} x_{2}+\epsilon
$$

Equation 1: Form of a standard least squares regression equation where $y$ is the response variable, $x_{1}$ is the first explanatory variable; $x_{2}$ is the second explanatory variable; $\beta_{0}$, $\beta_{1}$, and $\beta_{2}$ are parameters for the intercept, the first explanatory variable, and the second explanatory variable, respectively; and $\epsilon$ is an independent and normally distributed error term.

$$
\begin{aligned}
& \log _{10}(y)=\beta_{0}+\left(x_{1}-\beta_{1}\right) \times\left(\left(\log _{10}\left(x_{2}\right)-\beta_{2}\right) \times \beta_{3}\right)+ \\
& \beta_{4} x_{1}+\beta_{5} x_{2}+\epsilon
\end{aligned}
$$

Equation 2: Form of each response surface model prediction expression where $\log _{10}(y)$ is the response variable, $x_{1}$ is the first explanatory variable, $x_{2}$ is the second explanatory variable, $\beta_{0}$ is an intercept parameter, $\beta_{1}, \beta_{2}$, and $\beta_{3}$, are parameters for the cross-product terms, $\beta_{4}$ is a parameter multiplied by the first explanatory variable, $\beta_{5}$ is a parameter multiplied by the second explanatory variable, and $\epsilon$ is an independent and normally distributed error term.

Response surface models illustrate the nature of relations between three model parameters by using a two-dimensional kite-shaped surface that may be oriented, curved, and skewed in three dimensions to describe interaction between three variables: one (dependent) response variable and two (independent) explanatory variables. These interactions are illustrated in relief and can be rendered, animated, and explored as virtual three-dimensional objects using computer software.

\section{Model Verification and Diagnostics}

Evaluation of candidate models, using R-square, root mean square error (RMSE), and Akaike's Information Criterion adjusted for small samples (AICc), provided insights into the most appropriate candidate model choices for each regression equation describing discharge per square mile for each urban annual exceedance probability category. The R-square is a measure of the proportion of the total variance explained by the model. The R-square value indicated the proportion of variability in each relation that was accounted for by the statistical model - in this case a multiple regression model. $\mathrm{R}$-square values approaching 1 suggested increased explanatory power. The RMSE is an estimate of the error variance. The RMSE value indicated the differences between values predicted by each model and the values actually observed or measured. The RMSE helped to aggregate individual residual differences into a single measure of predictive power. The AICc measures the goodness of fit of an estimated statistical model. The AICc evaluates the model fit relative to the number of model covariates. The AICc value indicated the goodness of fit of each regression model, relative to other models, providing a tool for model selection. AICc values are grounded in the concept of entropy, offering a relative measure of the information lost when a given model is used. AICc describes the difference between model bias and model variance, or the tradeoff between model precision and model complexity. Models may be ranked by their AICc values. Lower AICc values were considered better than higher values (SAS Institute Inc., 2012).

Leverage plots (Sall, 1990), also known as "partialregression residual leverage plots" (Belsley and others, 1980), or "added variable plots" (Cook and Weisberg, 1982), were used to further investigate and screen candidate regression models. Leverage plots allow one to view the significance of each model parameter in the candidate regression model within the context of the larger model. The effect of a model parameter upon the larger model is displayed on the leverage plot by comparing the sum of squared residuals of the whole 
model to the sum of squared residuals of the model with the effect of interest removed. Residual errors that are smaller when the effect of a particular parameter is included in the model help confirm that the effect contributes significantly to the model fit. The leverage plot graphically displays this potential significance for each candidate explanatory variable, showing for each point in the model what the residual would be with and without the effect in the model. In the leverage plot, the distance from a point to the line of fit describes the actual residual. The distance from a point to the horizontal line of the mean describes the potential residual error if the effect were not part of the model. In other words, the mean line of the leverage plot represents the model if the value of the parameter effect were constrained to zero. The idea is to determine if the line of fit on the leverage plot for each explanatory variable carries each point on the plot significantly better than does the horizontal line of the mean shown on the plot. Leverage plots were used to identify (1) regression variables with significant explanatory power, (2) regression variables with borderline or insignificant explanatory power, and (3) regression variables exhibiting significant collinearity within the model. A leverage plot indicates that a regression variable has significant explanatory power if the slope of the line of fit is statistically distinct from the slope of the mean line, as shown in figure $4 \mathrm{~A}$. A leverage plot indicates that a regression variable has borderline or insignificant explanatory power if the slope of the line of fit is not statistically distinct from the slope of the mean line, as shown in figure $4 B$. A leverage plot indicates that a regression variable is exhibiting significant collinearity within the model if plotted points collapse toward a centroid, and the slope of the line of fit is not statistically distinct from the slope of the mean line, as shown in figure $4 C$.

Analyses of leverage plots for each potential explanatory variable in a candidate regression model afforded the opportunity to see the characteristics of each candidate variable, the influential strength of the variable, and its consequences within the larger model. The picture provided by each leverage

A

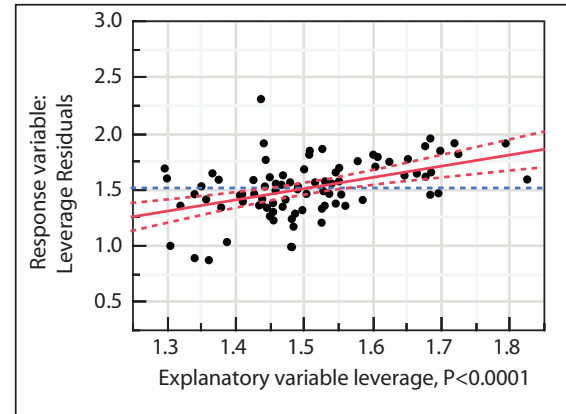

$B$

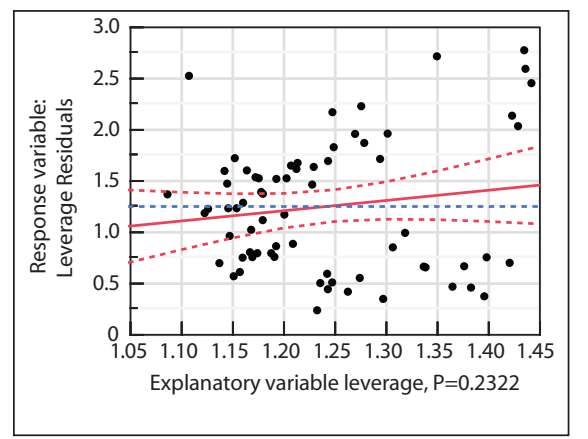

plot enabled a thorough, visual vetting of individual candidate model variables and a measure of confidence in variable selection that could not be obtained from non-graphical indices of collinearity and variable inflation, preparing a means to construct robust regressions. A leverage plot was constructed and evaluated for each model parameter in each candidate regression model. Models containing variables with significant explanatory power and limited collinearity were preferred as final candidates.

Selection of (1) $\log _{10}$-basin drainage area, and (2) basin percent urban area as explanatory variables yielded a robust regression in each model. Eight of the 15 urban peak-flow response surface models describing annual exceedance probability discharge per square mile in basins containing urban land, as a function of basin drainage area and basin percent urban area, yielded R-square values greater than 0.8. Actual-by-predicted plots were produced for model response variables, and leverage plots were produced for model explanatory variables in each peak-flow response category (fig. 5). Review of actual-by-predicted plots showed significant explanatory power $(\alpha=0.05)$ and robust, outlierresistant model fits for each of the 15 response surface models. Review of 45 explanatory variable leverage plots, 3 associated with each of the 15 response surface models, showed significant explanatory power $(\alpha=0.05)$ in 39 instances with no evidence of significant collinearity. The urban peak-flow response surface model describing 0.995 annual exceedance probability (1-year recurrence interval) discharge per square mile yielded an R-square value of 0.84 . The urban peak-flow response surface model describing 0.99 annual exceedance probability (1.01-year recurrence interval) discharge per square mile yielded an R-square value of 0.84 . The urban peak-flow response surface model describing 0.95 annual exceedance probability (1.05-year recurrence interval) discharge per square mile yielded an R-square value of 0.84 . The urban peak-flow response surface model describing 0.9 annual exceedance probability (1.11-year recurrence interval) discharge per square mile yielded an R-square value

Figure 4. Example leverage plots showing $(A)$ significant explanatory power, $(B)$ insignificant explanatory power and, $(C)$ evidence of collinearity. The solid red lines represent the significance of each explanatory model parameter, shown on the x-axis, within the context of the larger model. The dashed red lines represent the confidence interval of the significance of each explanatory model parameter. The dashed blue lines represent the horizontal line of the mean, describing the larger model if the effect of each explanatory model parameter were constrained to zero. The idea behind each leverage plot is to determine if the line of fit for each potential explanatory model variable carries each point on the plot significantly better than does the horizontal line of the mean shown on the plot. 
$\boldsymbol{A}$

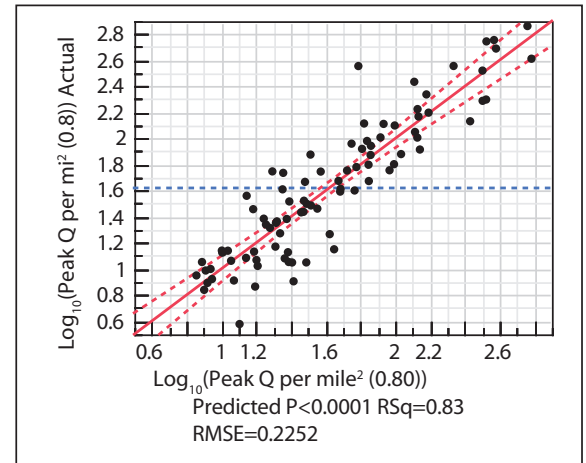

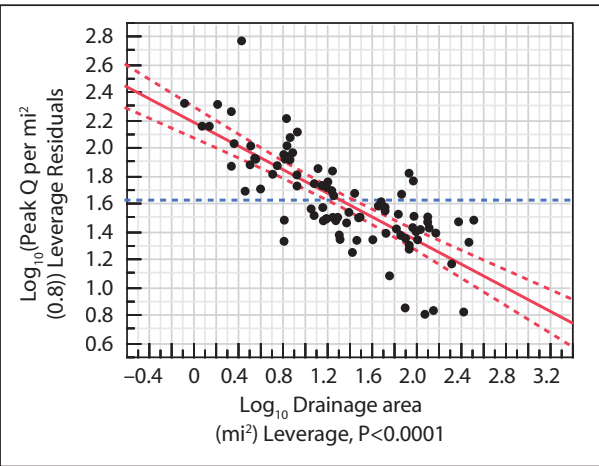

$c$

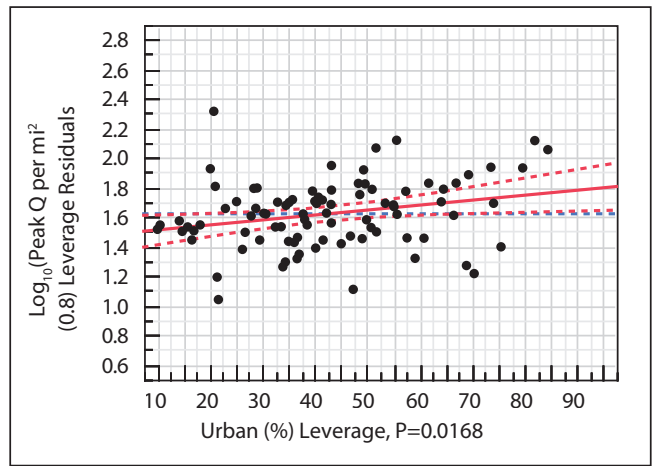

Figure 5. Plots for the 0.8 (1.25-year recurrence interval) model of urban peak flow per square mile showing $(A)$ actual-by-predicted values, $(B)$ drainage area explanatory power, and $(C)$ urban area explanatory power ( 0 denotes discharge).

of 0.83 . The urban peak-flow response surface model describing 0.8 annual exceedance probability (1.25-year recurrence interval) discharge per square mile yielded an R-square value of 0.83 . The urban peak-flow response surface model describing 0.67 annual exceedance probability (1.5-year recurrence interval) discharge per square mile yielded an R-square value of 0.82 . The urban peak-flow response surface model describing 0.5 annual exceedance probability (2-year recurrence interval) discharge per square mile yielded an R-square value of 0.81 . The urban peak-flow response surface model describing 0.43 annual exceedance probability (2.33-year recurrence interval) discharge per square mile yielded an R-square value of 0.81 . The urban peak-flow response surface model describing 0.2 annual exceedance probability (5-year recurrence interval) discharge per square mile yielded an R-square value of 0.76 . The urban peak-flow response surface model describing 0.1 annual exceedance probability (10-year recurrence interval) discharge per square mile yielded an R-square value of 0.74 . The urban peak-flow response surface model describing 0.04 annual exceedance probability (25-year recurrence interval) discharge per square mile yielded an R-square value of 0.69 . The urban peak-flow response surface model describing 0.02 annual exceedance probability (50-year recurrence interval) discharge per square mile yielded an R-square value of 0.65 . The urban peak-flow response surface model describing 0.01 annual exceedance probability (100-year recurrence interval) discharge per square mile yielded an R-square value of 0.57 . The urban peak-flow response surface model describing 0.005 annual exceedance probability (200-year recurrence interval) discharge per square mile yielded an R-square value of 0.55 . The urban peak-flow response surface model describing 0.002 annual exceedance probability (500-year recurrence interval) discharge per square mile yielded an R-square value of 0.44 . Urban peak-flow response surface regression equations are found in table 3 .

\section{Model Limitations}

These models provide meaningful estimates when applied to the area for which they are developed, using values of explanatory variables within the range of data values used for model development (figs. 1, 2). They are not meant for use with the high or low endpoints of each explanatory variable range, or values outside of these limits. Application of urban peak-flow response surface models is limited to all drainage basins contained within the boundaries of the Commonwealth of Virginia that range in size from no less than $1.2 \mathrm{mi}^{2}$ to no more than 2,400 $\mathrm{mi}^{2}$ and contain no less than 10 percent and no more than 96 percent urban area.

\section{Urban Peak Flow Per Square Mile Estimates}

Urban peak-flow response surface models provide a three-dimensional representation of change in peak flow per square mile, as a function of basin drainage area and basin percent urban land area. In each figure (figs. 6-21), a kiteshaped model response surface is shown in green. Black circles plot the data used to fit each model. In each figure, the relation among the three variables - two explanatory variables, $\log _{10}$-basin drainage area (in square miles) and basin urban area (in percent), and one response variable, $\log _{10}$-peak flow per square mile - may be traced along the green kiteshaped surface. Each response surface changes in a non-linear fashion relative to changes in basin drainage area and basin urban area.

The best available estimates of basin square mile drainage area are recommended for $\log _{10}$-transformation and use as the first of two explanatory variables. Accurate basin square mile drainage area values are important because estimates of urban area annual peak flow per square mile may not be true if inaccurate explanatory values are used. One source of these estimates is U.S. Geological Survey Open-File Report 
2006-1308, "Drainage areas of selected streams in Virginia" (Hayes and Wiegand, 2006). Hayes and Wiegand provide a list of drainage area values for selected Virginia basins. These same basin drainage area values are also available as basin characteristics listed in table 6 of Austin and others (2011b). Krstolic (2006) provides the digital boundaries associated with these basins.

Urban land cover data developed by Homer and others (Homer and others, 2004) are recommended as source data for calculating basin percent urban area, the second of two explanatory variables. This is because accurate urban land cover values are required to ensure true estimates of urban area annual peak flow per square mile. These urban land cover data are labeled as NLCD2001 Land Cover (Version 2.0) and are available from the National Land Cover Database hosted by the Multi-Resolution Land Characteristics Consortium Web site (http://www.mrlc.gov/nlcd2001.php, accessed September 20, 2013). Land cover data from four combined land cover classes within this database were summarized to determine percent urban area. These four land cover classes are: (1) Class 21: developed, open space; (2) Class 22: developed, low intensity; (3) Class 23: developed, medium intensity; and (4) Class 24: developed, high intensity. A ratio of land area occupied by the combined four urban land cover classes to the total basin drainage area was calculated to yield basin percent urban area (Austin and others 2011b). Because models were developed using the basin urban area percentages prepared from these data, it is recommended that any new basin urban area percentages be developed using the most up-to-date iteration of this dataset. Doing so will help ensure accurate estimates of urban area annual peak flow per square mile. At the time this report was written (2013), the most up-to-date dataset was available online from the Multi-Resolution Land Characteristics Consortium Web site (http://www.mrlc.gov/nlcd06_data.php). An alternative to preparing new basin urban area percentages is to use the values previously reported by the U.S. Geological Survey and used to develop the models and equations listed in this report. These previously reported basin urban area percentages may be found in table 6 of Austin and others (2011b).

Figure 6 illustrates how to read each three-dimensional response surface model plot. Enter the plot along the top, (or bottom), axis of each of the two explanatory variables, $\log _{10}$-basin drainage area and basin urban area. Find the explanatory variable values of interest on each explanatory

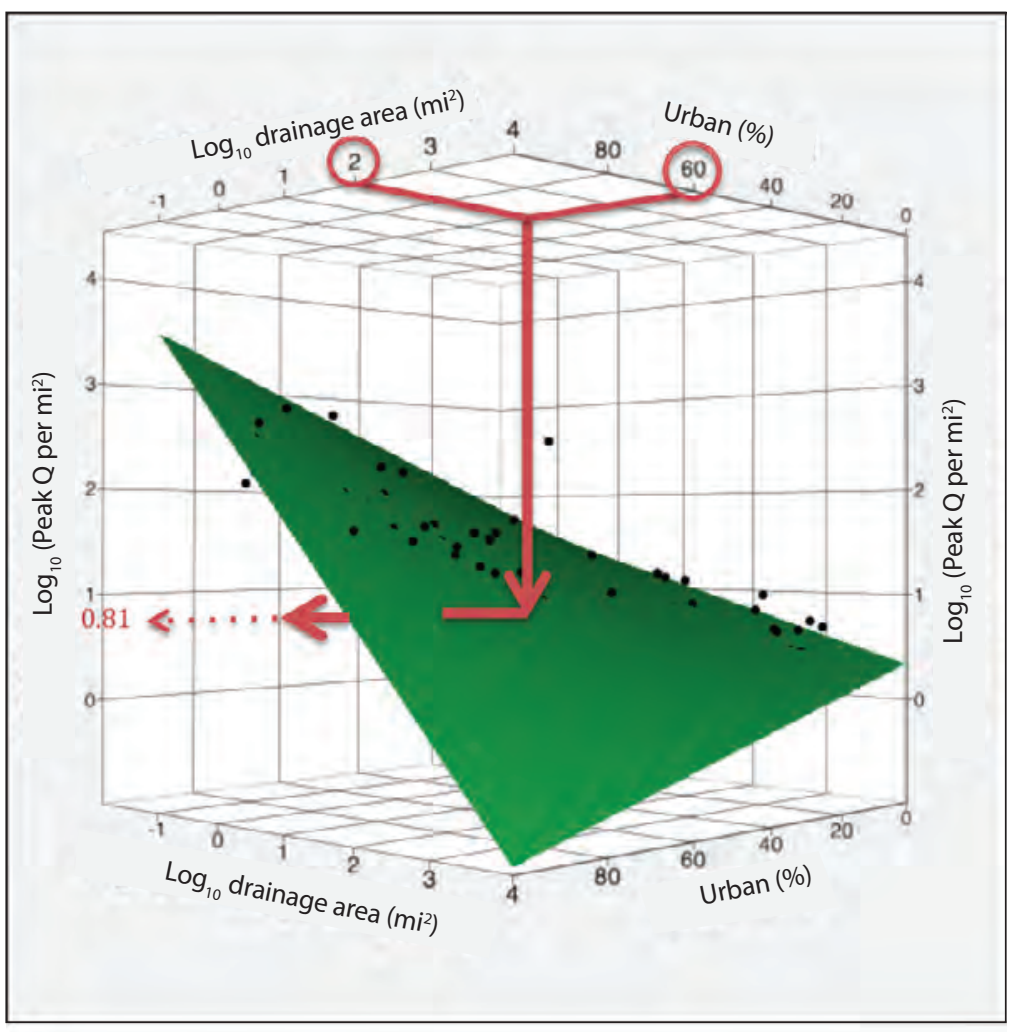

Figure 6. How to read three-dimensional response surface model plots: Find the explanatory variable values of interest on each explanatory variable axis, then trace across the top grid (or bottom grid) to locate the point at which these values converge. From the point of convergence, project a line downward (or upward) to an intersection point on the green response surface. From the intersection point, read across to intersect the grid associated with the axis of the response variable, $\log _{10}$-peak flow per square mile. Project a line from this point to the response variable axis, and read the result. This pathway is illustrated in red ( 0 denotes discharge). 
variable axis, then trace across the top grid (or bottom grid) to locate the point at which these values converge. From the point of convergence, project a line downward (or upward) to an intersection point on the green response surface. From the intersection point, read across to intersect the grid associated with the axis of the response variable, $\log _{10}$-peak flow per square mile. Project a line from this point to the response variable axis, and read the result. The response surfaces for each of 15 models describing urban discharge per square mile annual exceedance probabilities are illustrated in figures 7-21. The equations in table 3 may be used to determine urban discharge per square mile annual exceedance probabilities. Example calculations are provided in the report section titled Examples of Applying the Equations.

Response surface models for each urban basin peakflow probability category indicate strong correlation between (1) basin peak flow per square mile and basin percent urban area, and (2) basin peak flow per square mile and $\log _{10}$-basin drainage area. The shapes of response surface models also suggest that interaction between basin percent urban area and $\log _{10}$-basin drainage area may influence basin peak flow per square mile. The curvilinear shape of each kite in each response surface model plot suggests a synergistic relation associated with the interaction of basin percent urban area and $\log _{10}$-basin drainage area. This relation yields non-linear increases in urban peak flows per square mile with increasing basin percent urban area and decreasing $\log _{10}$-basin drainage area. This relation may reflect the reinforcing consequences of structural changes in basin surface and sub-surface flow paths combining the increasing density of impervious surfaces, subsurface piping, storm drains, and sewer installations, and the decreasing precipitation infiltration rates associated with urban development. Reduced infiltration rates, accelerated rates of water flow across impervious surfaces, and rapid concentration of water flow through pipes, storm drains, and sewers combine to increase net water volume and shorten water travel distances and travel times, increasing water flow rates.

These effects of urban change on surface-water volumes, water travel times, and water discharge rates have also been identified and characterized in previous studies, most notably in Virginia by Anderson $(1968,1970)$. In his 1970 report, Anderson illustrates the dramatic increase in urban peak flows and equally dramatic decrease in lag-times associated with urban hydrographs, as urban basins transition from natural channels with natural basin surfaces, to completely sewered basins having natural basin surfaces, to, finally, completely sewered basins having highly impervious basin surfaces (Anderson, 1970, page C4, fig. 2). While the empirical equations describing the process-based interactions of precipitation, impervious surface, channel straightening, and piping of water flows as described by Anderson may not be directly comparable to the statistical relations identified in response surface models, both methods of analysis identify significant increases in urban peak stream discharges as basin urban area grows. The statistical relations identified in response surface models support the empirically determined characterizations of change in physical processes reported by Anderson (figs. 7-21). Leverage plots of response surface model crossed-product effects that multiply basin percent urban area by $\log _{10}$-basin drainage area affirm these reinforcing responses, showing a statistically significant cross-product interaction between basin percent urban area and $\log _{10}$-basin drainage area in response surface models for 11 of the 15 peak flow per square mile probability categories, and no evidence of explanatory variable cross-product collinearity in the 15 peakflow probability response surface models (fig. 22). Actual-bypredicted plots, shown in figures $23-37$, illustrate the strength of predicted outcomes for each response surface model.

Interestingly, in response surface models that characterize the four highest-flow annual exceedance probability categories $0.02,0.01,0.005$, and 0.002 (recurrence intervals of 50, 100, 200 , and 500 years, respectively), absence of statistically significant cross-product interactions is also consistent with the nature of urban basin streamflow. During these highest flows basin soils are often saturated and stream channels are often overwhelmed by water. In these instances most of an urban basin drainage system may be inundated. Any interaction effects between basin percent urban area and basin square mile drainage area may be less meaningful as predictors of urban area peak-flow response during these events.

Response surface models correctly signal this shift. For the four highest-flow annual exceedance probability categories $0.02,0.01,0.005$, and 0.002 (recurrence intervals of 50, 100, 200 , and 500 years, respectively) response surface models show that basin percent urban area and basin square mile drainage area are statistically significant predictors, exhibiting significant explanatory power $(\alpha=0.05)$ in each of these four response categories. Cross-product interactions between basin percent urban area and basin square mile drainage area, however, demonstrate insignificant explanatory power $(\alpha=0.05)$ in each of these four highest-flow response categories. Visual cues to this shift are evident when comparing the forms of the green kite-shaped surfaces in each response surface model plot. Response surface model plots for annual exceedance probabilities $0.02,0.01,0.005$, and 0.002 (figs. 18-21) are more planer in shape (less curved) than plots for the remaining annual exceedance probability categories (figs. 7-17), signaling cross-product interactions with less explanatory power than those shown in the other plots. 


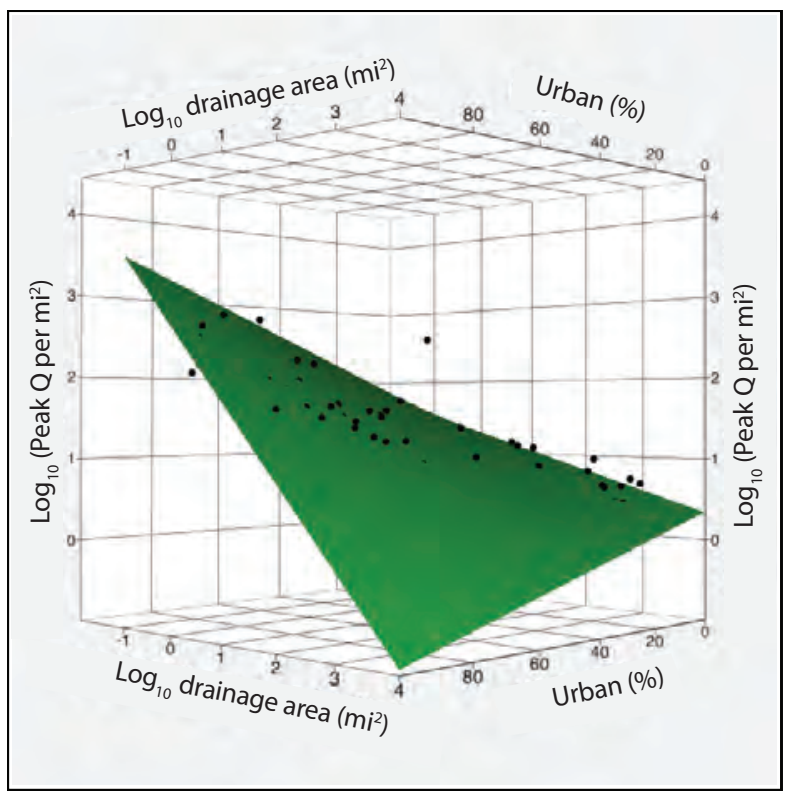

Figure 7. Urban peak flow (0) per square mile response surface model for 0.995 annual exceedance probability (1-year recurrence interval) streamflow in Virginia ( 0 denotes discharge).

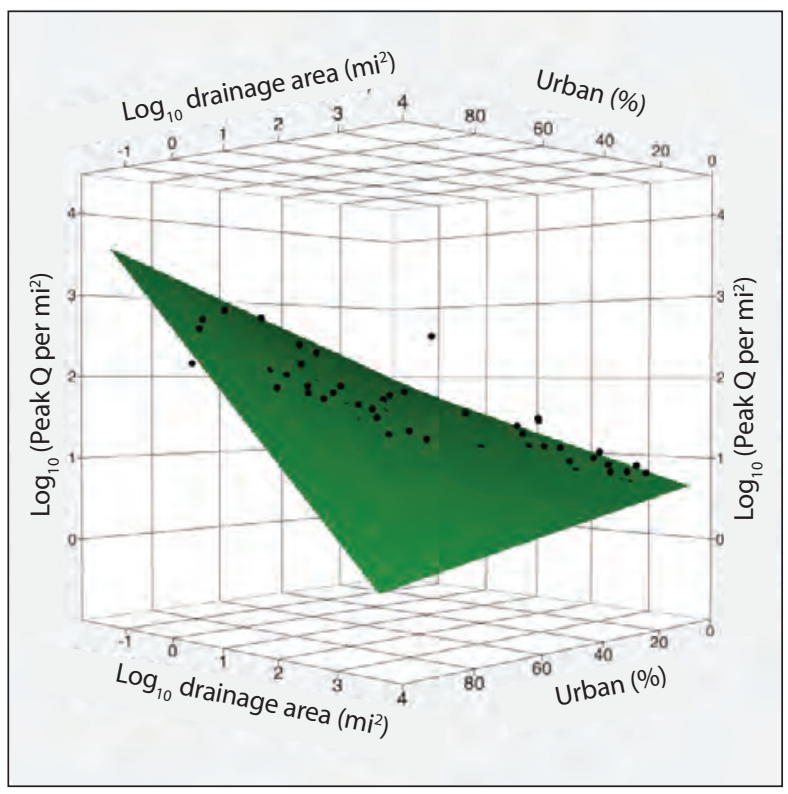

Figure 9. Urban peak flow (0) per square mile response surface model for 0.95 annual exceedance probability (1.05-year recurrence interval) streamflow in Virginia ( 0 denotes discharge).

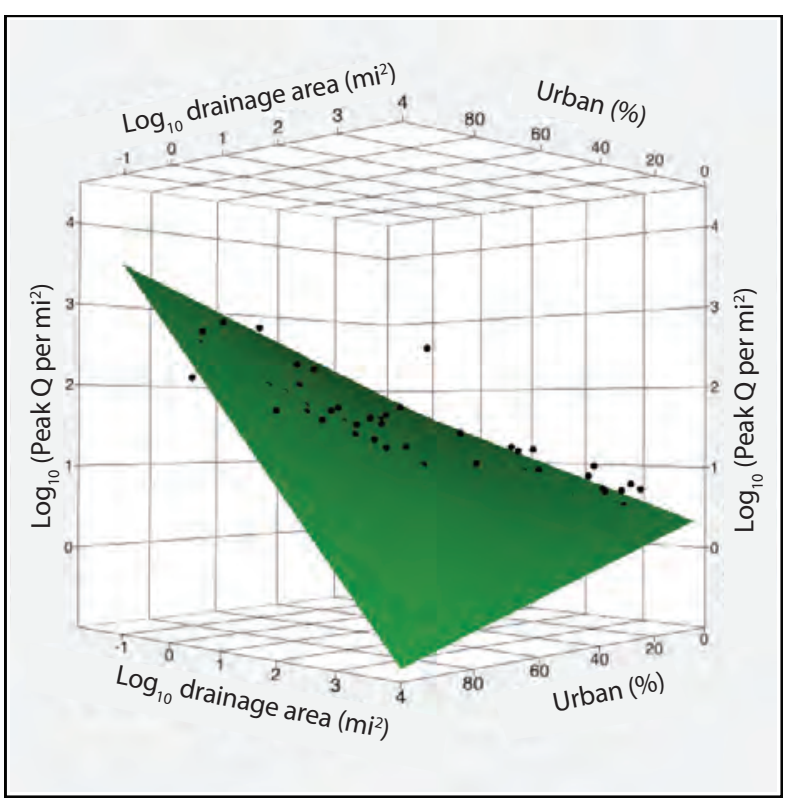

Figure 8. Urban peak flow (0) per square mile response surface model for 0.99 annual exceedance probability (1.01-year recurrence interval) streamflow in Virginia ( 0 denotes discharge).

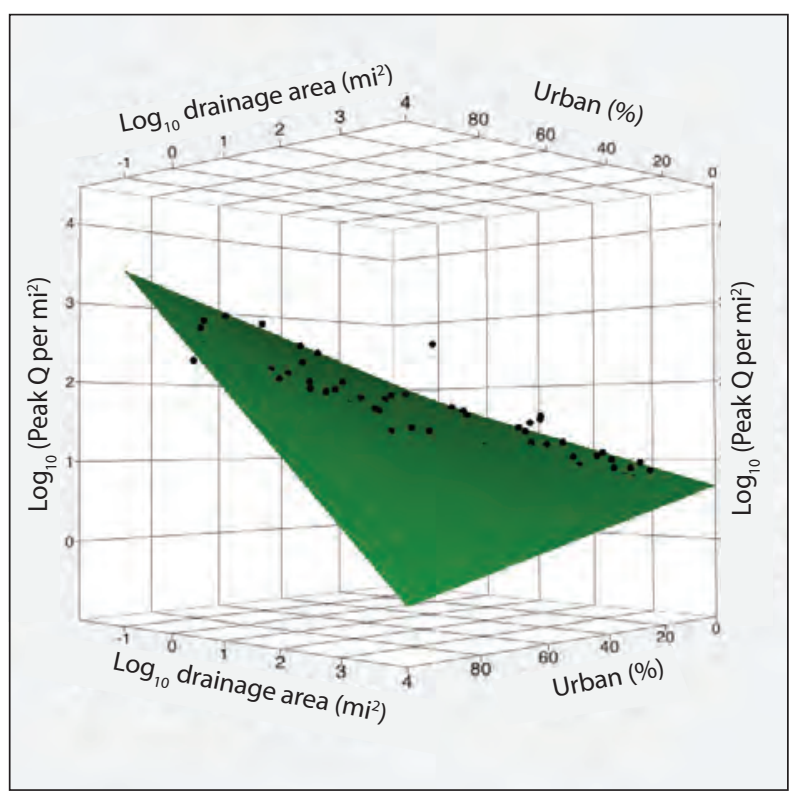

Figure 10. Urban peak flow (0) per square mile response surface model for 0.9 annual exceedance probability (1.11-year recurrence interval) streamflow in Virginia ( 0 denotes discharge). 


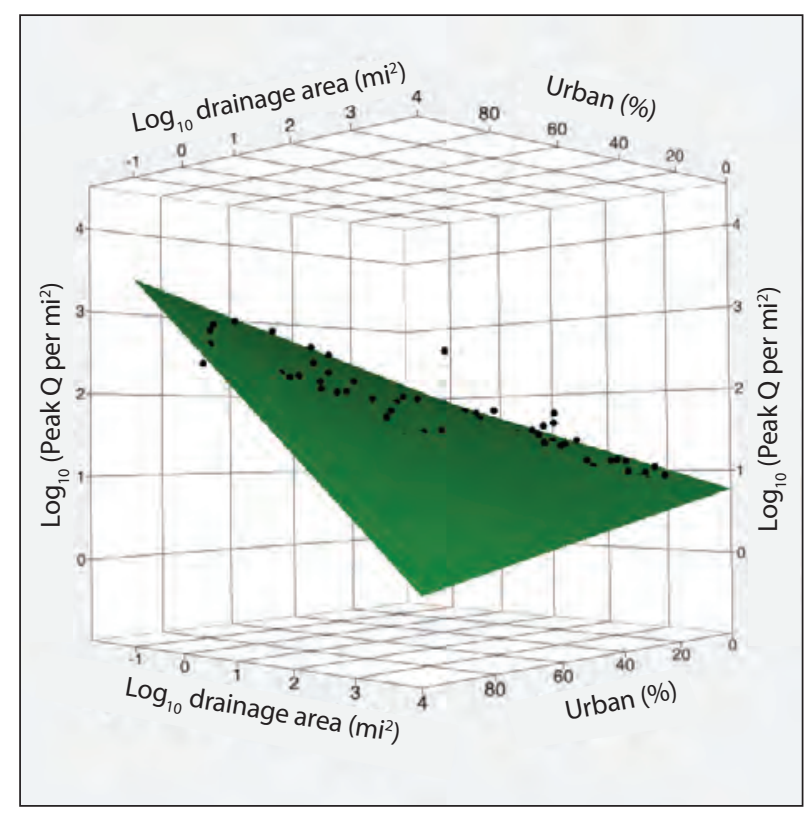

Figure 11. Urban peak flow (0) per square mile response surface model for 0.8 annual exceedance probability (1.25-year recurrence interval) streamflow in Virginia ( 0 denotes discharge).

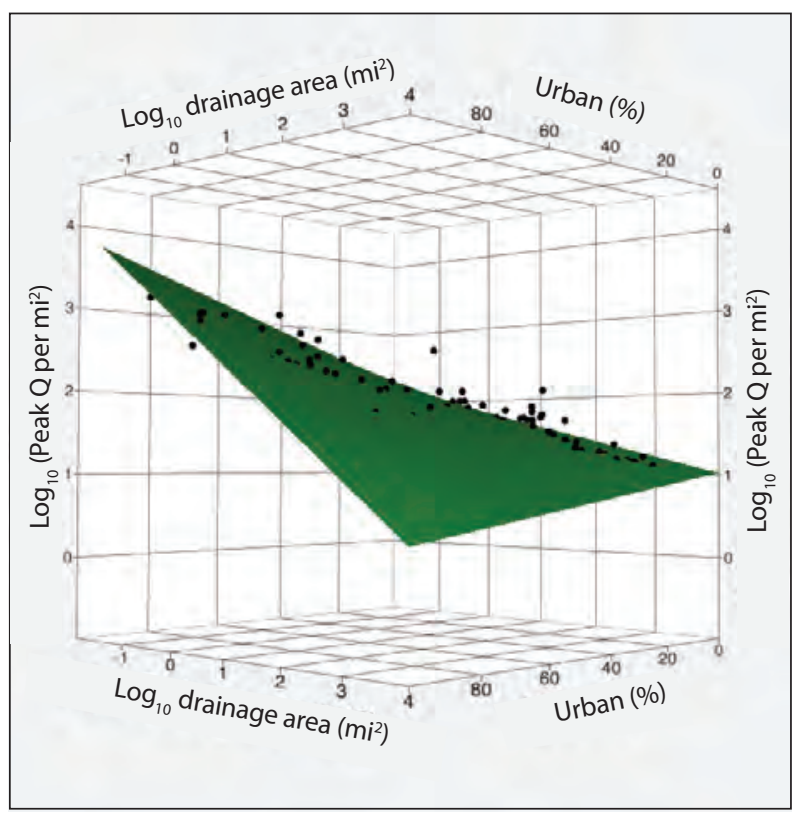

Figure 13. Urban peak flow (0) per square mile response surface model for 0.5 annual exceedance probability (2-year recurrence interval) streamflow in Virginia ( 0 denotes discharge).

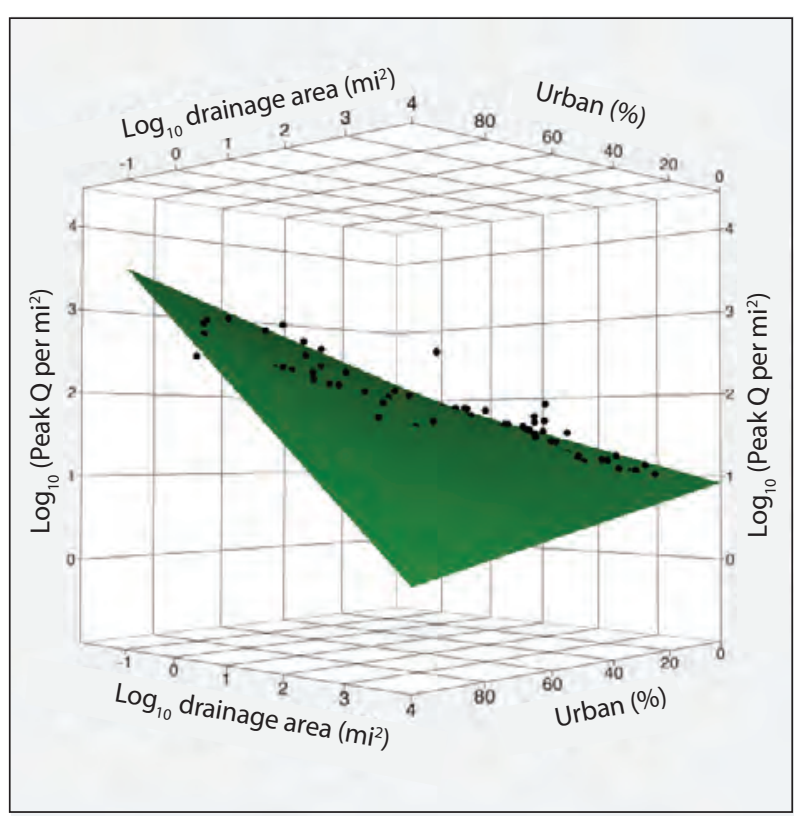

Figure 12. Urban peak flow $(0)$ per square mile response surface model for 0.67 annual exceedance probability (1.5-year recurrence interval) streamflow in Virginia ( 0 denotes discharge).

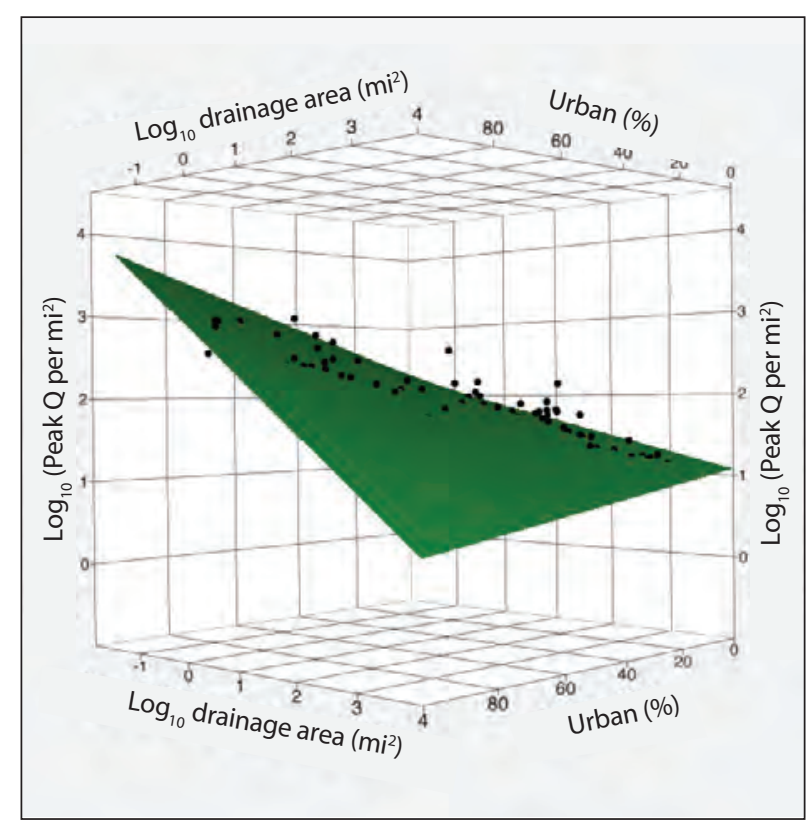

Figure 14. Urban peak flow (0) per square mile response surface model for 0.43 annual exceedance probability (2.33-year recurrence interval) streamflow in Virginia ( 0 denotes discharge). 


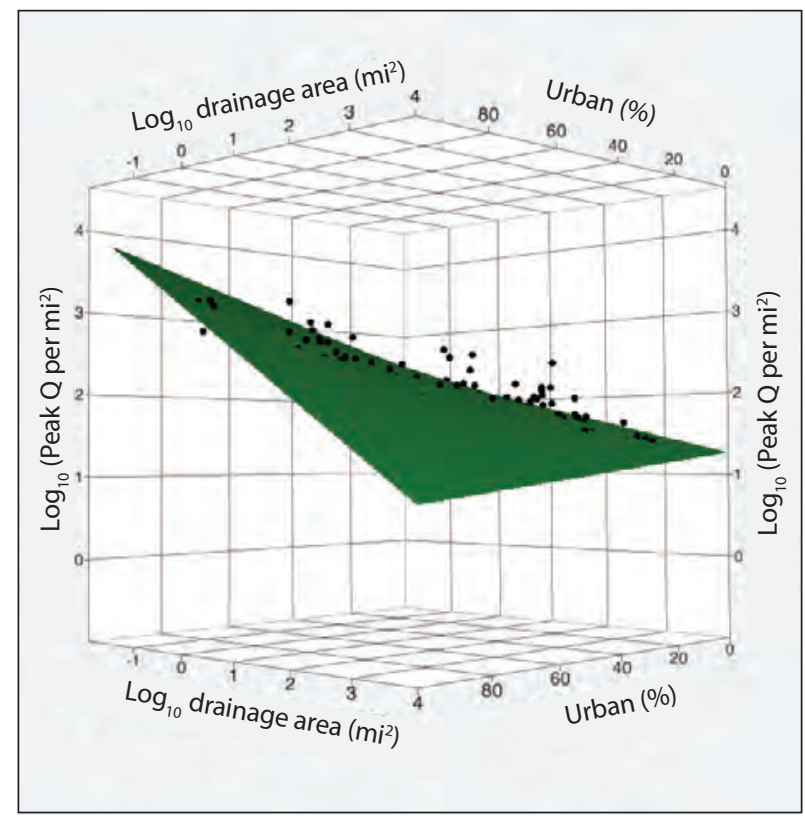

Figure 15. Urban peak flow (0) per square mile response surface model for 0.2 annual exceedance probability (5-year recurrence interval) streamflow in Virginia ( 0 denotes discharge).

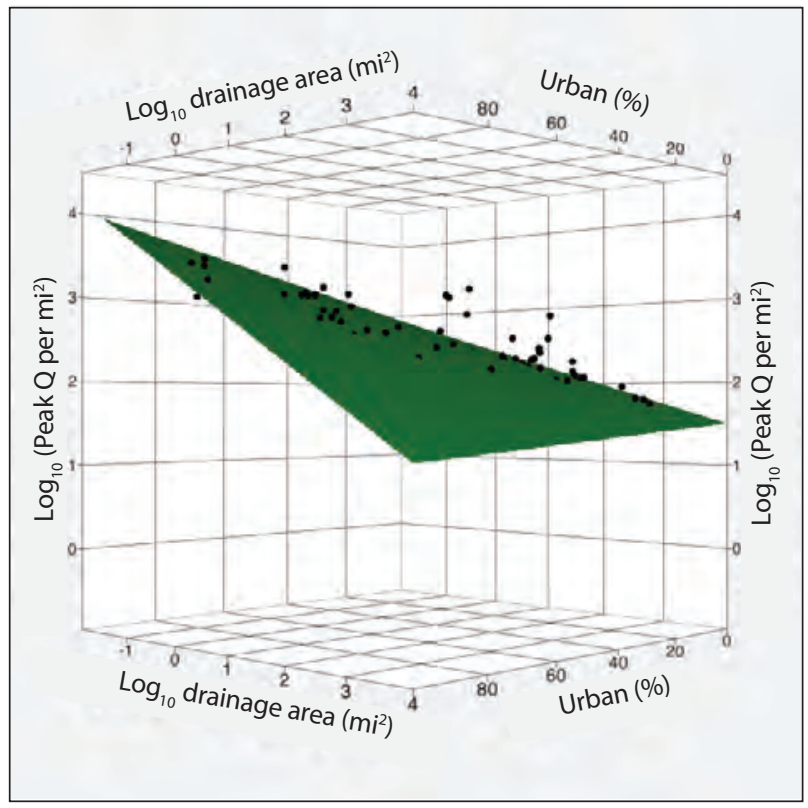

Figure 17. Urban peak flow (0) per square mile response surface model for 0.04 annual exceedance probability (25-year recurrence interval) streamflow in Virginia ( 0 denotes discharge).

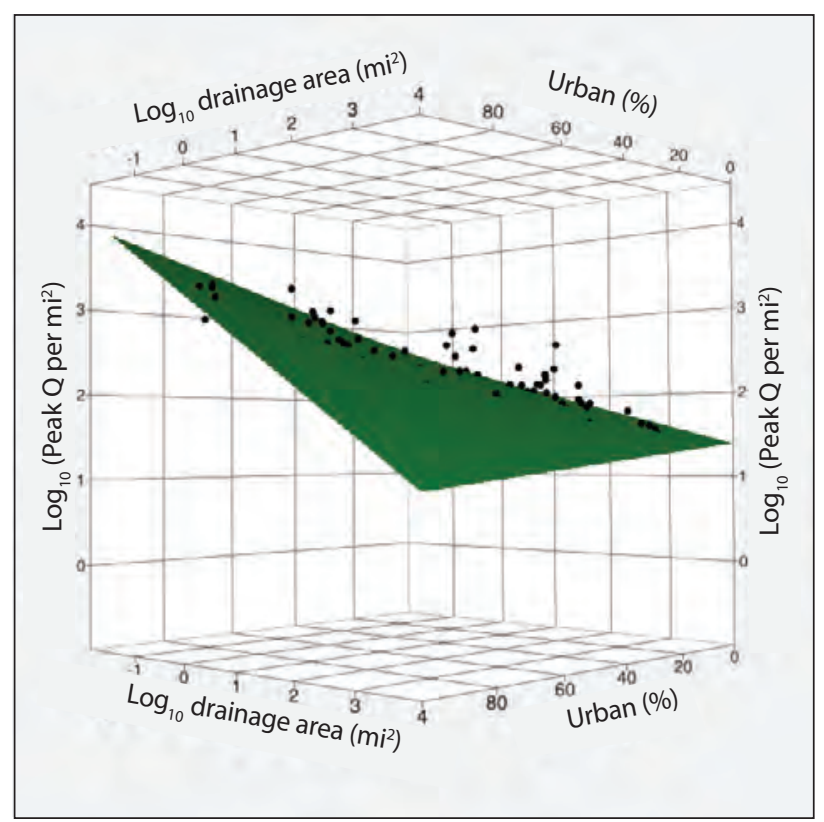

Figure 16. Urban peak flow (0) per square mile response surface model for 0.1 annual exceedance probability (10-year recurrence interval) streamflow in Virginia ( 0 denotes discharge).

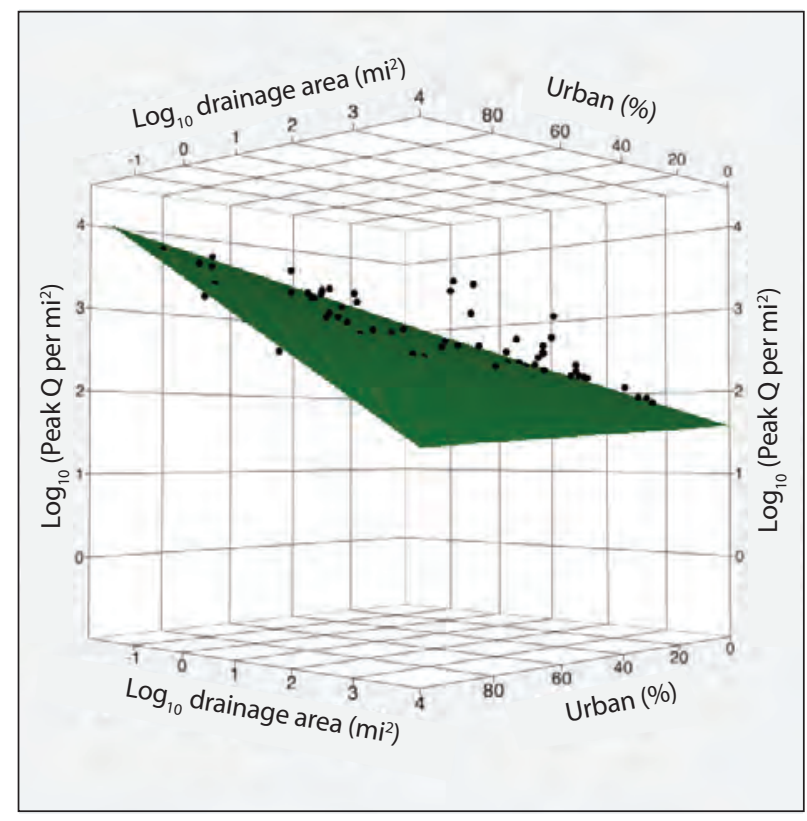

Figure 18. Urban peak flow (0) per square mile response surface model for 0.02 annual exceedance probability (50-year recurrence interval) streamflow in Virginia ( 0 denotes discharge). 


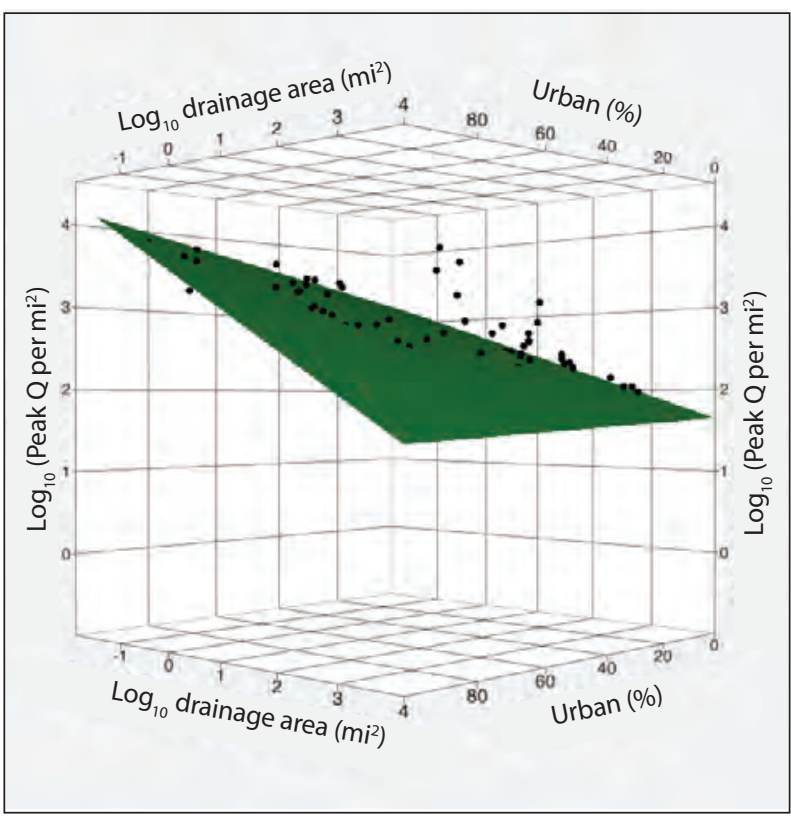

Figure 19. Urban peak flow (0) per square mile response surface model for 0.01 annual exceedance probability (100-year recurrence interval) streamflow in Virginia ( 0 denotes discharge).

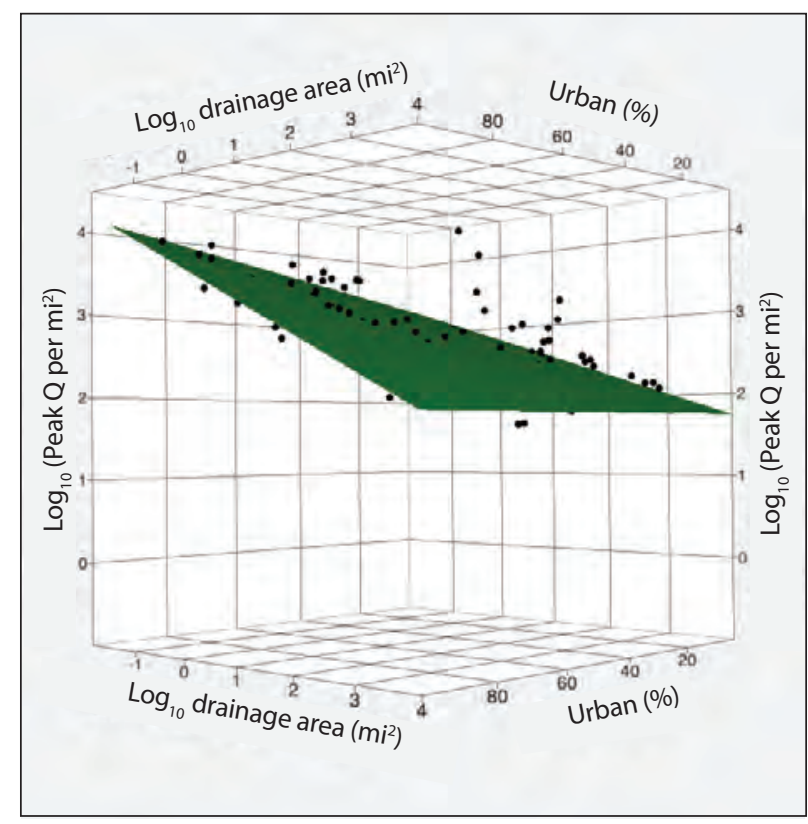

Figure 20. Urban peak flow (0) per square mile response surface model for 0.005 annual exceedance probability (200-year recurrence interval) streamflow in Virginia ( 0 denotes discharge).

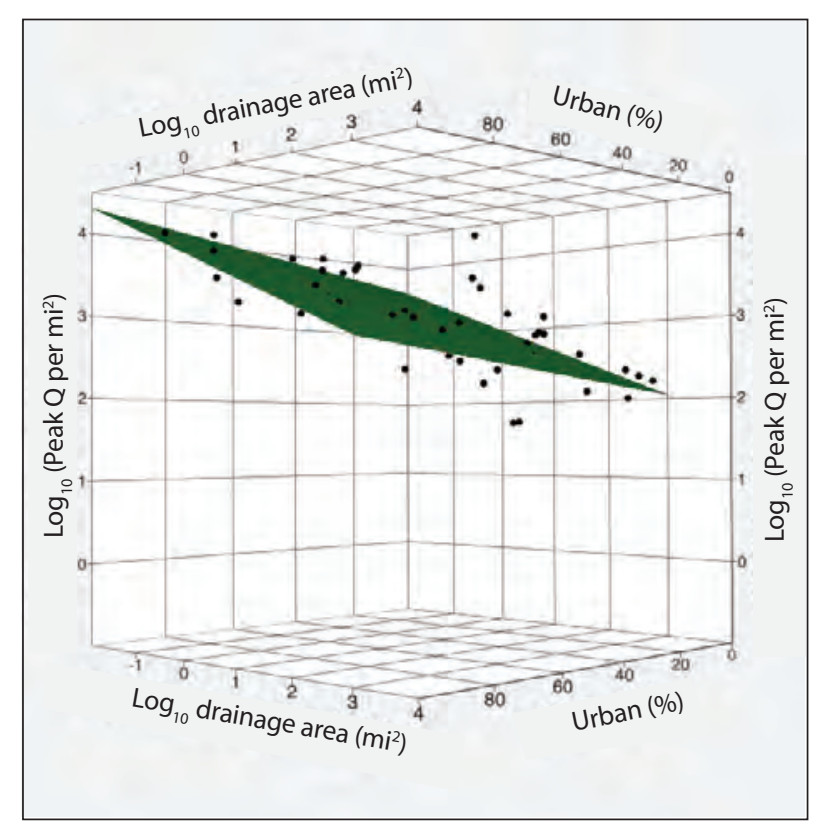

Figure 21. Urban peak flow (0) per square mile response surface model for 0.002 annual exceedance probability (500-year recurrence interval) streamflow in Virginia ( 0 denotes discharge). 
$\boldsymbol{A}$

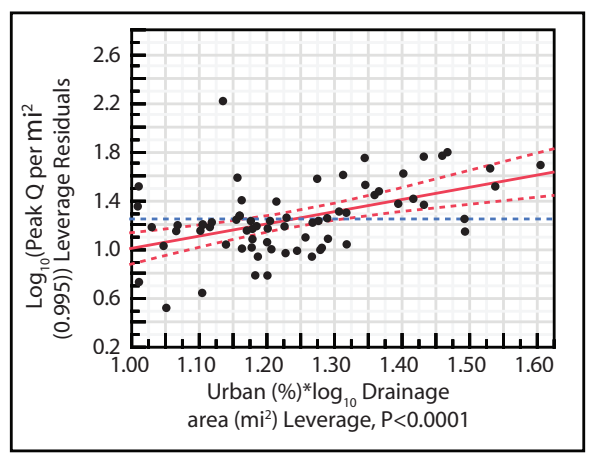

D

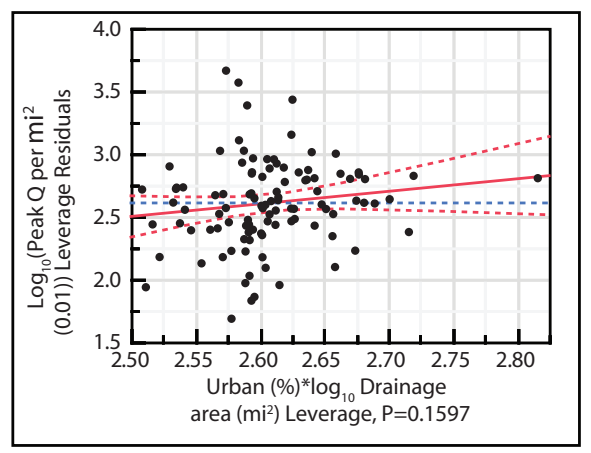

B

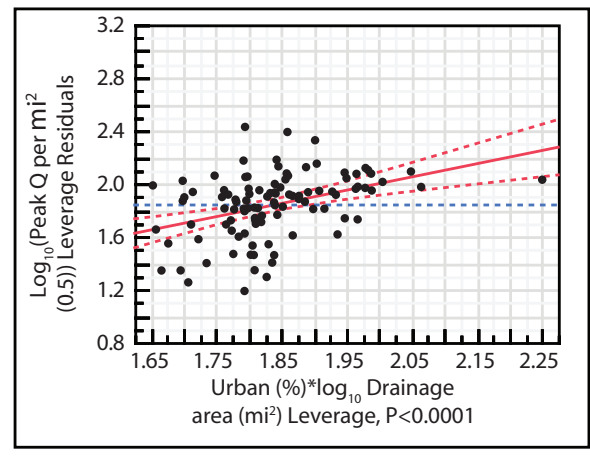

$\boldsymbol{E}$

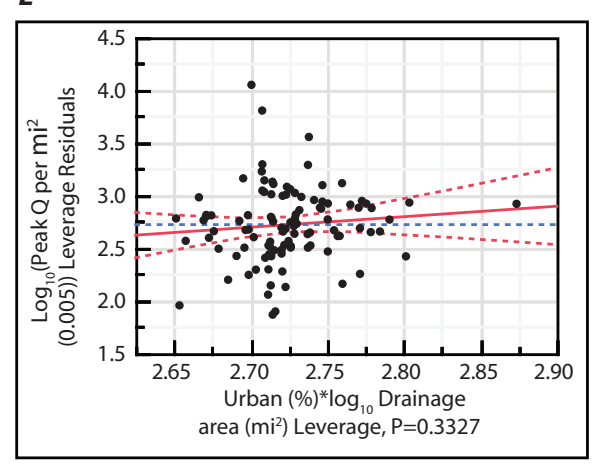

$c$

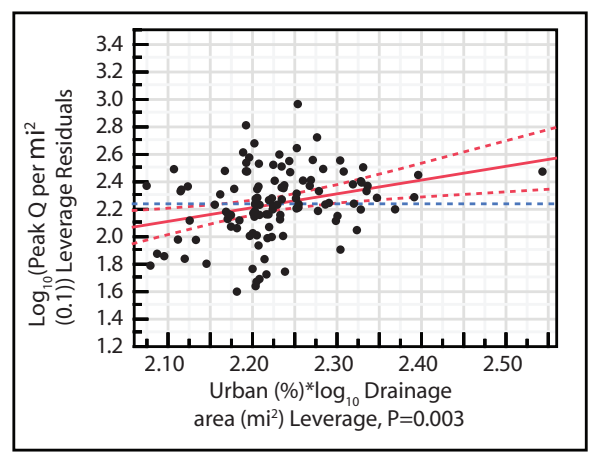

$\boldsymbol{F}$

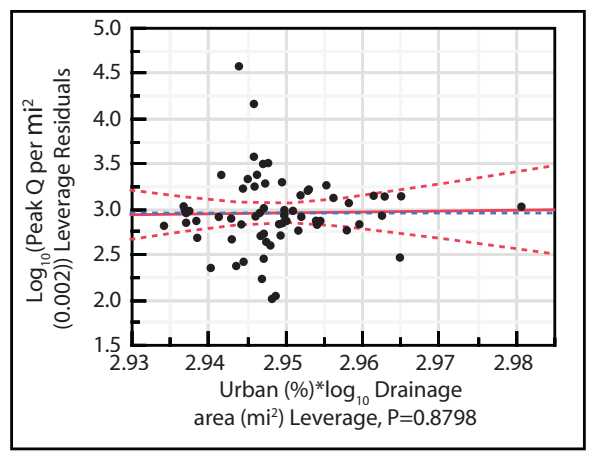

Figure 22. Leverage plots indicating statistically significant cross-product effects in response surface models for $(A) 0.995,(B)$ 0.50 and $(C) 0.10$ urban peak flow probability categories (recurrence intervals of 1 year, 2 years, and 10 years, respectively), and insignificant cross-product effects in response surface models for $(D) 0.01,(E) 0.005$, and $(F) 0.002$ urban peak-flow probability categories (recurrence intervals of 100 years, 200 years, and 500 years, respectively). Each leverage line in plots $A, B$, and $C$ is statistically distinct from the blue-dashed horizontal line of the mean. Each leverage line in plots $D, E$, and $F$ is not statistically distinct from the blue-dashed horizontal line of the mean. Dispersion of points along each leverage line signals no evidence of collinearity among cross-product explanatory variables ( 0 denotes discharge).

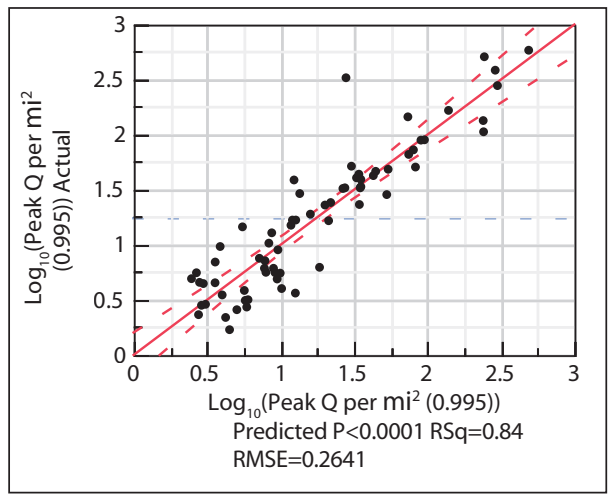

Figure 23. Urban peak flow (0) per square mile actual-by-predicted plot for 0.995 annual exceedance probability (1-year recurrence interval) streamflow in Virginia (0 denotes discharge).

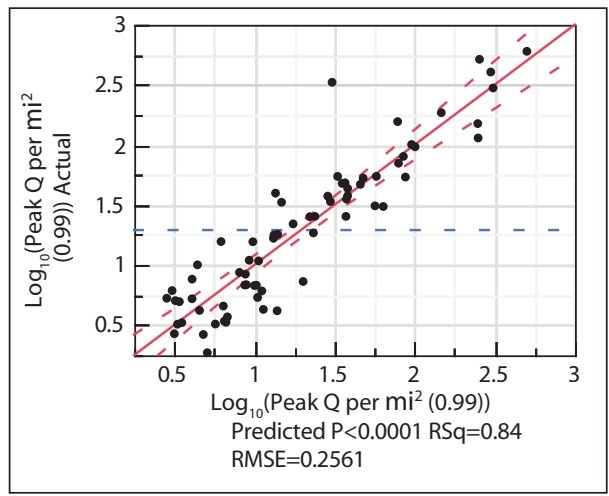

Figure 24. Urban peak flow (0) per square mile actual-by-predicted plot for 0.99 annual exceedance probability (1.01-year recurrence interval) streamflow in Virginia ( 0 denotes discharge).

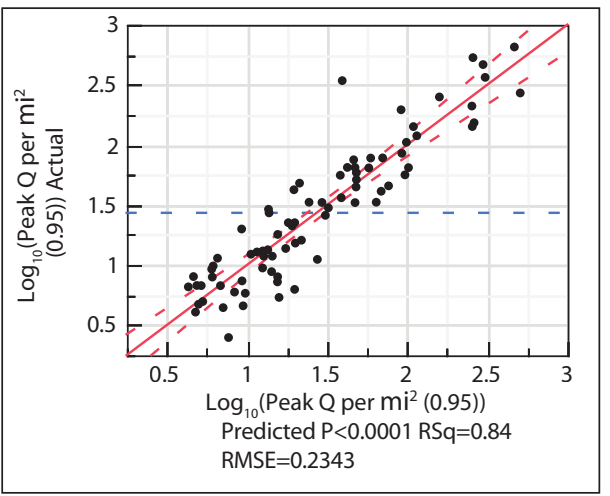

Figure 25. Urban peak flow (0) per square mile actual-by-predicted plot for 0.95 annual exceedance probability (1.05-year recurrence interval) streamflow in Virginia ( 0 denotes discharge). 


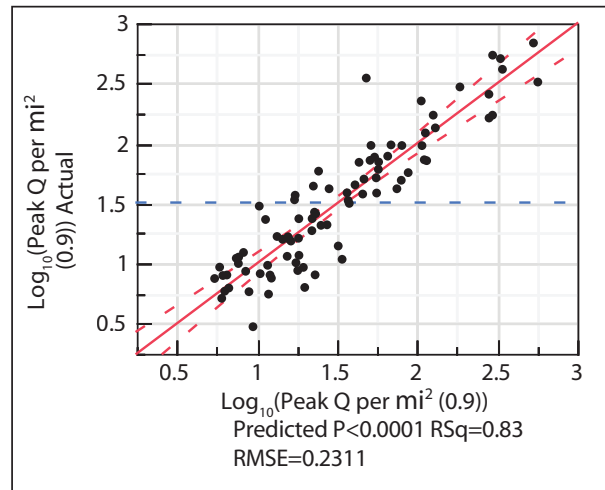

Figure 26. Urban peak flow (0) per square mile actual-by-predicted plot for 0.9 annual exceedance probability (1.11-year recurrence interval) streamflow in Virginia ( 0 denotes discharge).

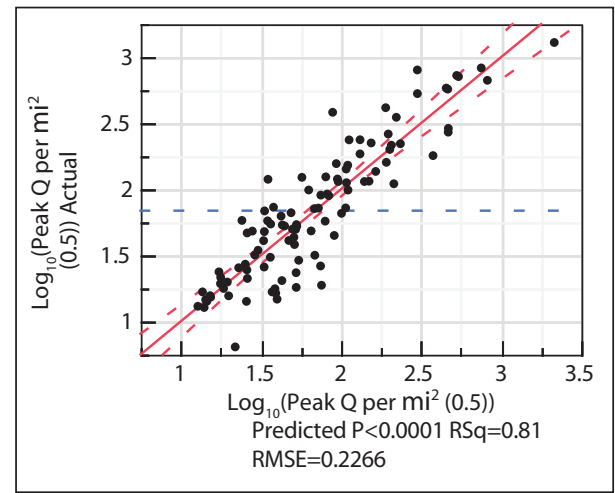

Figure 29. Urban peak flow (0) per square mile actual-by-predicted plot for 0.5 annual exceedance probability (2-year recurrence interval) streamflow in Virginia ( 0 denotes discharge).

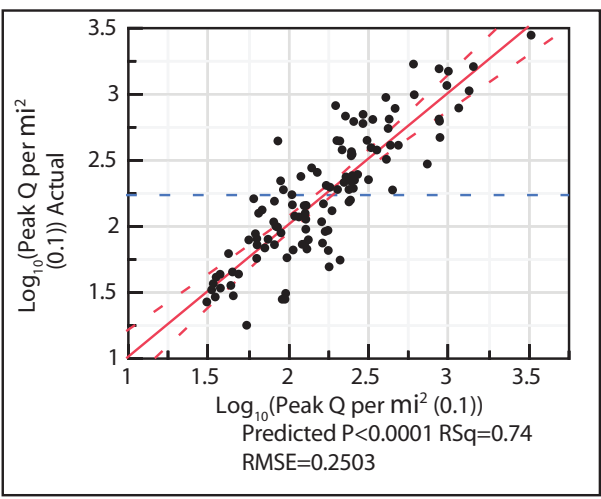

Figure 32. Urban peak flow (0) per square mile actual-by-predicted plot for 0.1 annual exceedance probability (10-year recurrence interval) streamflow in Virginia ( 0 denotes discharge).

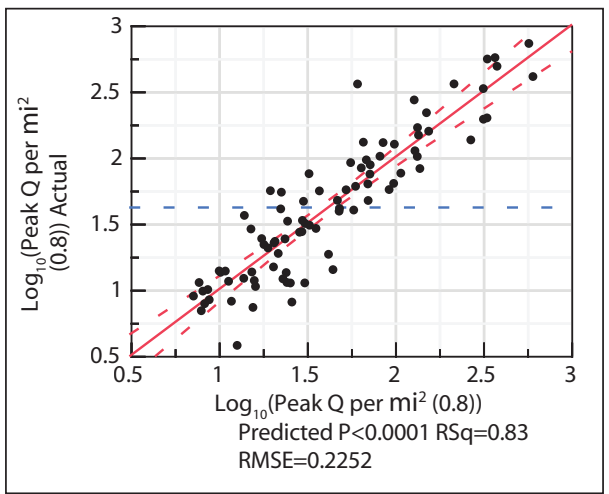

Figure 27. Urban peak flow (0) per square mile actual-by-predicted plot for 0.8 annual exceedance probability (1.25-year recurrenc interval) streamflow in Virginia ( 0 denotes discharge).

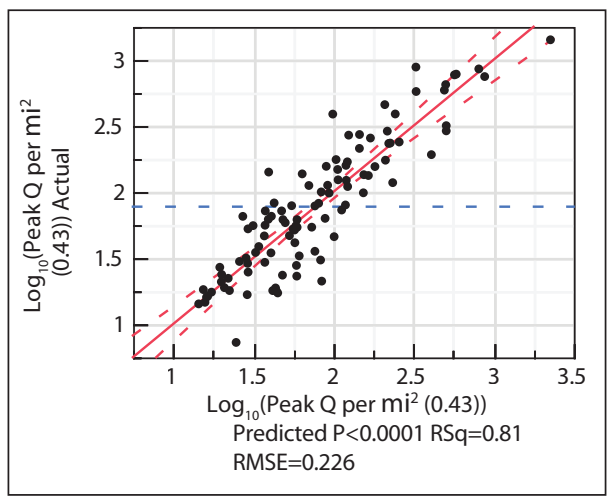

Figure 30. Urban peak flow (0) per square mile actual-by-predicted plot for 0.43 annual exceedance probability (2.33-year recurrence interval) streamflow in Virginia ( 0 denotes discharge).

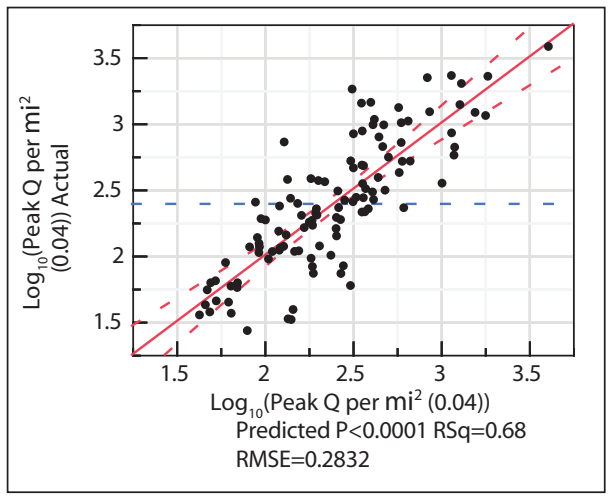

Figure 33. Urban peak flow (0) per square mile actual-by-predicted plot for 0.04 annual exceedance probability (25-year recurrence interval) streamflow in Virginia ( 0 denotes discharge).

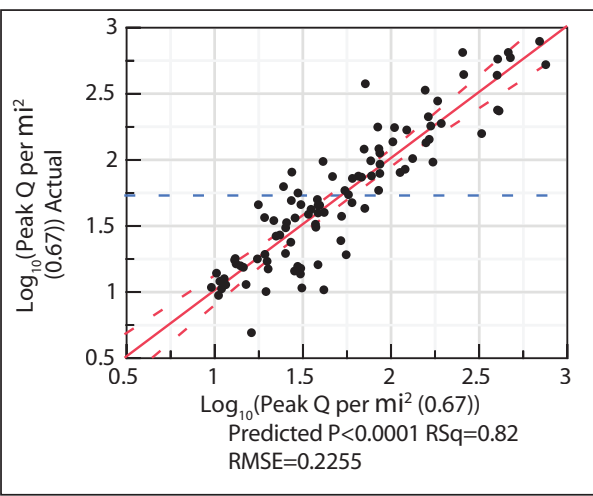

Figure 28. Urban peak flow (0) per square mile actual-by-predicted plot for 0.67 annual exceedance probability (1.5-year recurrence interval) streamflow in Virginia ( 0 denotes discharge).

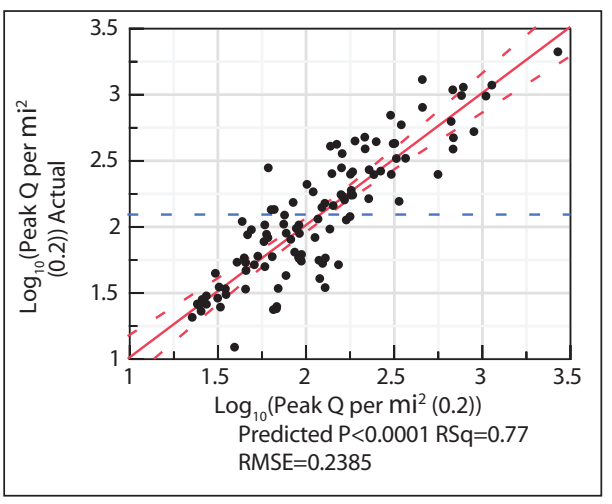

Figure 31. Urban peak flow (0) per square mile actual-by-predicted plot for 0.2 annual exceedance probability (5-year recurrence interval) streamflow in Virginia ( 0 denotes discharge).

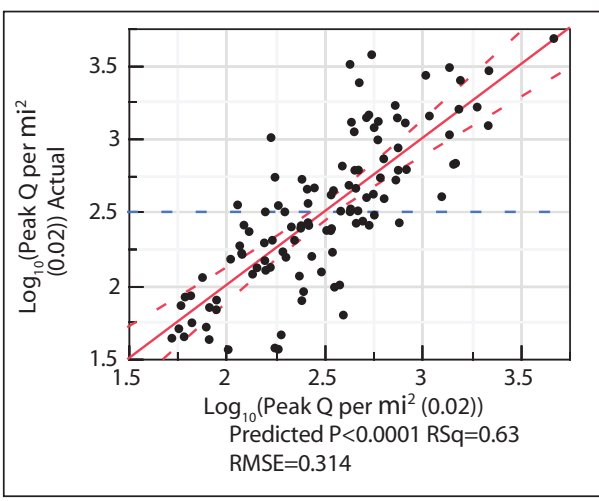

Figure 34. Urban peak flow (Q) per square mile actual-by-predicted plot for 0.02 annual exceedance probability (50-year recurrence interval) streamflow in Virginia ( $Q$ denotes discharge). 


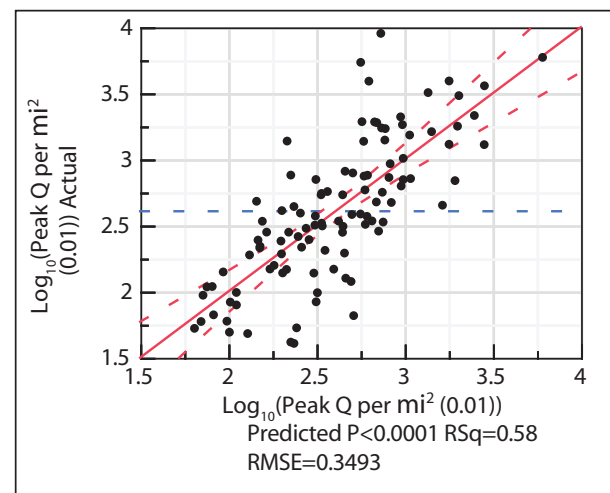

Figure 35. Urban peak flow (0) per square mile actual-by-predicted plot for 0.01 annual exceedance probability (100-year recurrence interval) streamflow in Virginia ( 0 denotes discharge).

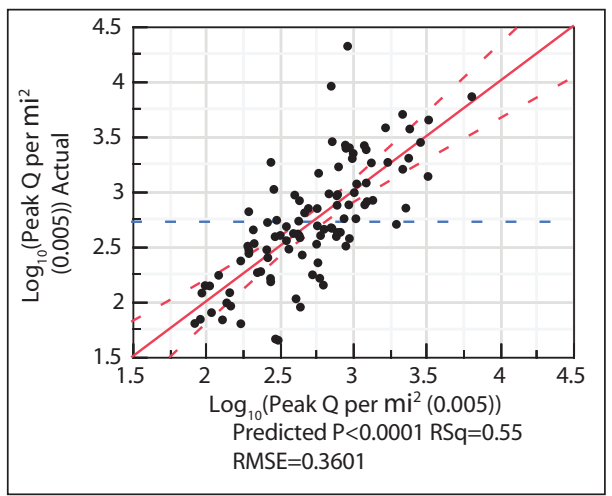

Figure 36. Urban peak flow (0) per square mile actual-by-predicted plot for 0.005 annual exceedance probability (200-year recurrence interval) streamflow in Virginia ( 0 denotes discharge).

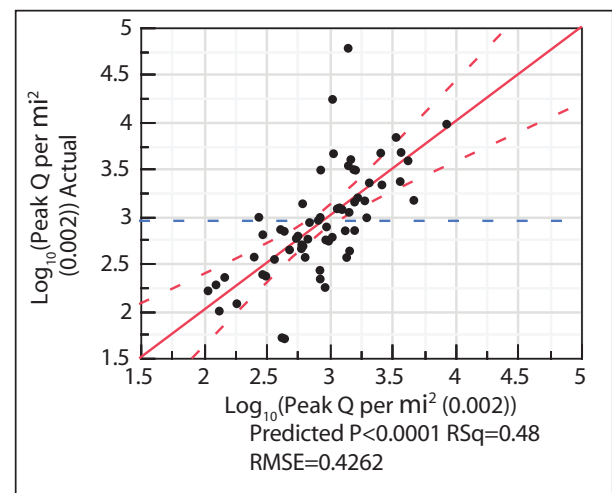

Figure 37. Urban peak flow (0) per square mile actual-by-predicted plot for 0.002 annual exceedance probability (500-year recurrence interval) streamflow in Virginia ( 0 denotes discharge).

\section{Examples of Applying the Equations}

Two step-by-step examples are presented that demonstrate how to perform calculations using the equations in this report to estimate peak flow per square mile in urban areas. The first example demonstrates how to estimate the 1.11-year (0.9 annual exceedance probability) urban peak flow per square mile for a drainage basin with an upstream area of $10 \mathrm{mi}^{2}, 60$ percent of which is classified as urban area. The second example demonstrates how to estimate the 10 -year ( 0.10 annual exceedance probability) urban peak flow per square mile for a drainage basin with an upstream area of $95 \mathrm{mi}^{2}, 15$ percent of which is classified as urban area.

\section{Example 1}

Estimate the 1.11-year (0.9 annual exceedance probability) urban peak flow per square mile for a drainage basin with an upstream area of $10 \mathrm{mi}^{2}, 60$ percent of which is classified as urban area.

Given: 1. Drainage area (DA) of $10.0 \mathrm{mi}^{2}$ for the upstream area of this basin, measured from a 1:24,000-scale topographic map. 2. Urban area (URBAN) upstream of the measurement point is estimated as 60 percent of the upstream basin drainage area, from data developed by Homer and others (2004) and available from the Multi-Resolution Land Characteristics Consortium Web site (http://www.mrlc.gov).

Solution: The estimated urban peak flow per square mile for the site is computed by using the appropriate regression equation prediction expression in table 3 . For 1.11 years $(0.9$ annual exceedance probability), equation 4 in table 3 is used to compute urban peak flow per square mile as follows:

$\log _{10}(0.9$ AEP peak per square mile $)=1.869+$

$(\mathrm{URBAN}-42.339) \times\left(\left(\log _{10}(\mathrm{DA})-1.340\right) \times-0.00523\right)+$

$0.00323 \times \mathrm{URBAN}+-0.446 \times \log _{10}(\mathrm{DA})$

(equation 4 from table 3 ).
The $10-\mathrm{mi}^{2}$ drainage area (DA) and the 60 percent urban area (URBAN) are entered into the equation as follows:

$$
\begin{aligned}
& \log _{10}(0.9 \text { AEP peak per square mile })=1.869+ \\
& (60-42.339) \times\left(\left(\log _{10}(10)-1.340\right) \times\right. \\
& -0.00523)+0.00323 \times 60+-0.446 \times \log _{10}(10)
\end{aligned}
$$

The equation then simplifies to

$\log _{10}(0.9$ AEP peak per square mile $)=1.648$

This $\log _{10}(0.9$ AEP peak per square mile) value is converted to a non- $\log _{10}$ value as an exponent of 10, as follows:

$$
=10^{1.648}=44.46 \mathrm{ft}^{3} / \mathrm{s} \text {. }
$$

The 1.11-year (0.9 annual exceedance probability) urban peak flow per square mile for a drainage basin with an upstream area of $10 \mathrm{mi}^{2}, 60$ percent of which is classified as urban area, is estimated as $44.46 \mathrm{ft}^{3} / \mathrm{s}$.

\section{Example 2}

Estimate the 10-year ( 0.1 annual exceedance probability) urban peak flow per square mile for a drainage basin with an upstream area of $95 \mathrm{mi}^{2}, 15$ percent of which is classified as urban area.

Given: 1. Drainage area (DA) of $95.0 \mathrm{mi}^{2}$ for the upstream area of this basin, measured from a 1:24,000-scale topographic map. 2. Urban area (URBAN) upstream of the measurement point is estimated as 15 percent of the upstream basin drainage area, from data developed by Homer and others (2004) and available from the Multi-Resolution Land Characteristics Consortium Web site (http://www.mrlc.gov). 
Solution: The estimated urban peak flow per square mile for the site is computed by using the appropriate equation in table 3 . For 10 years ( 0.1 annual exceedance probability), equation 10 in table 3 is used to compute urban peak flow per square mile as follows:

$$
\begin{aligned}
& \log _{10}(0.1 \text { AEP peak per square mile })=2.373+ \\
& (\text { URBAN }-38.706) \times\left(\left(\log _{10}(D A)-1.103\right) \times\right. \\
& -0.00313)+0.00470 \times \text { URBAN }+-0.334 \times \log _{10}(D A) \\
& \text { (equation } 10 \text { from table } 3) .
\end{aligned}
$$

The $95-\mathrm{mi}^{2}$ drainage area (DA) and the 15 percent urban area (URBAN) are entered into the equation as follows:

$$
\begin{aligned}
& \log _{10}(0.1 \text { AEP peak per square mile })=2.373+ \\
& (15-38.706) \times\left(\left(\log _{10}(95)-1.103\right) \times\right. \\
& -0.00313)+0.00470 \times 15+-0.334 \times \log _{10}(95)
\end{aligned}
$$

The equation then simplifies to

$$
\log _{10}(0.1 \text { AEP peak per square mile })=1.848 \text {. }
$$

This $\log _{10}(0.1$ AEP peak per square mile $)$ value is converted to a non- $\log _{10}$ value as an exponent of 10 , as follows:

$$
=10^{1.848}=70.47 \mathrm{ft}^{3} / \mathrm{s}
$$

The 10-year ( 0.1 annual exceedance probability) urban peak flow per square mile for a drainage basin with an upstream area of $95 \mathrm{mi}^{2}, 15$ percent of which is classified as urban area, is estimated as $70.47 \mathrm{ft}^{3} / \mathrm{s}$.

\section{Summary}

Anticipating high-flow conditions in Virginia's urban streams is essential to sound management of water resources and associated riparian and watershed ecosystems. Reliable predictions of urban peak flows inform planning and design, improving management of Virginia's urban basins. The U.S. Geological Survey, in cooperation with the Virginia Department of Transportation, has developed a set of 15 response surface models that describe Virginia urban area peak streamflow per square mile based on changes in basin percent urban area and basin drainage area. A total of 115 Virginia drainage basins were selected for analysis, each containing at least 10 percent urban area, and not more than 96 percent urban area, and ranging in size from 0.07 to 2,404 square miles $\left(\mathrm{mi}^{2}\right)$.

Equations for each response surface model may be used to estimate Virginia urban peak streamflow per square mile of basin drainage area for annual exceedance probabilities of $0.995,0.99,0.95,0.9,0.8,0.67,0.5,0.43,0.2,0.1,0.04$, $0.02,0.01,0.005$, and 0.002 (recurrence intervals of 1.005 , $1.01,1.05,1.11,1.25,1.49,2.0,2.3,5,10,25,50,100,200$, and 500 years, respectively). Equations provide meaningful estimates when applied using values of explanatory variables inside the range of data values used for model development. They are not meant for use outside of these limits. Application of urban peak-flow response surface models and equations is limited to drainage basins contained within the boundaries of the Commonwealth of Virginia that range in size from no less than $1.2 \mathrm{mi}^{2}$ to no more than $2,400 \mathrm{mi}^{2}$ and contain no less than 10 percent and no more than 96 percent urban area. Examples are provided demonstrating use of the equations.

Streams in urban areas serve important functions, and the effects of urbanization upon stream systems are significant. Changes in runoff processes result from covering parts of a basin with impervious roofs, sidewalks, roadways, and parking lots. Stormwaters accumulate downstream more quickly than in natural stream systems, producing higher flood peaks. Increased water velocities in stream channels decrease the lag between rainfall and runoff. Decreased lag times ensure that peak flow rates must increase, even if total water volumes remain constant, but total water volumes actually increase since net infiltration of precipitation is reduced as a consequence of impervious surfaces. This increase in total water volume drives flood peaks even higher than they would be if water volumes remained constant.

Increased peak flows in urbanizing basins lead to significant consequences that must be identified and anticipated by urban planners, designers, and managers. Predictions of urban streamflows provide knowledge for better protection from floods, anticipation of water availability during critical periods, and improved planning and management of water resources.

Actual-by-predicted plots for model response variables and leverage plots for model explanatory variables showed significant explanatory power $(\alpha=0.05)$ and robust model fits for 15 response surface models and significant explanatory power $(\alpha=0.05)$ for explanatory variables in 39 of 45 instances, with no evidence of explanatory variable collinearity. Equations for 8 of 15 urban peak-flow response surface models yield R-square values greater than 0.8. Urban peak flow response surface models describing annual exceedance probabilities of $0.995,0.99,0.95,0.9,0.8,0.67,0.5,0.43,0.2$, $0.1,0.04,0.02,0.01,0.005$, and 0.002 (recurrence intervals of $1.005,1.01,1.05,1.11,1.25,1.49,2.0,2.3,5,10,25,50,100$, 200 , and 500 years, respectively), yield R-square values of $0.84,0.84,0.84,0.83,0.83,0.82,0.81,0.81,0.76,0.74,0.69$, $0.65,0.57,0.55$, and 0.44 , respectively. 


\section{Selected References}

Aitchison, J., and Brown, J.A.C., 1957, The lognormal distribution: Cambridge, U.K., Cambridge University Press, $176 \mathrm{p}$.

Anderson, D.G., 1968, Effects of urban development on floods in northern Virginia: U.S. Geological Survey Open-File Report, $26 \mathrm{p}$.

Anderson, D.G., 1970, Effects of urban development on floods in northern Virginia: U.S. Geological Survey Water-Supply Paper 2001-C, 27 p.

Austin, S.H., Krstolic, J.L., and Wiegand, Ute, 2011a, Lowflow characteristics of Virginia streams: U.S. Geological Survey Scientific Investigations Report 2011-5143, 122 p. + 9 tables on CD. (Also available online at http://pubs.usgs. gov/sir/2011/5143/.)

Austin, S.H., Krstolic, J.L., and Wiegand, Ute, 2011b, Peakflow characteristics of Virginia streams: U.S. Geological Survey Scientific Investigations Report 2011-5144, 106 p. +3 tables and 2 appendixes on CD. (Also available online at http://pubs.usgs.gov/sir/2011/5144/.)

Austin, S.H., and Wiegand, U., 2009, Annual maximum stages and discharges of selected streams in Virginia through 2007: U.S. Geological Survey Open-File Report 2009-1007, 733 p., accessed September 20, 2013, at http://pubs.water.usgs.gov/ ofr2009-1007.

Belsley, D.A., Kuh, E., and Welsch, R.E., 1980, Regression diagnostics: New York, John Wiley and Sons, 292 p.

Benson, M.A., 1962, Factors influencing the occurrence of floods in a humid region of diverse terrain: U.S. Geological Survey Water-Supply Paper 1580-B, 64 p.

Benson, M.A., 1964, Factors affecting the occurrence of floods in the southwest: U.S. Geological Survey Water-Supply Paper 1580-D, 72 p.

Berenbrock, C., 2002, Estimating the magnitude of peak flows at selected recurrence intervals for streams in Idaho: U.S. Geological Survey Water-Resources Investigations Report 02-4170, 59 p.

Booth, D.B., and Jackson, R.C., 1997, Urbanization of aquatic systems - Degradation thresholds, stormwater detection, and the limits of mitigation: American Water Resources Association, Water Resources Bulletin, v. 33, no. 5, p. 1077-1090.

Cook, R.D., and Weisberg, S., 1982, Residuals and influence in regression: N.Y., Chapman and Hall, 229 p.
Cushing, E.M., Kantrowitz, I.H., and Taylor, K.R., 1973, Water resources of the Delmarva Peninsula: U.S. Geological Survey Professional Paper 822, 58 p.

Dillow, J.A., 1996, Technique for estimating magnitude and frequency of peak flows in Maryland: U.S. Geological Survey Water-Resources Investigations Report 95-4154, 55 p.

Dunne, T., and Leopold, L.B., 1978, Water in environmental planning: San Francisco, W.H. Freeman Co., 818 p.

Focazio, M.J., Woodside, M.D., and Cooper, R.E., 1993, Effects of wetlands on water quality downstream from an urbanized area in Virginia [abs.]: Joint meeting of The American Society of Limnology and Oceanography and The Society of Wetland Scientists: Edmonton, Alberta, Canada, 1993, 1 p.

Fry, J., Xian, G., Jin, S., Dewitz, J., Homer, C., Yang, L., Barnes, C., Herold, N., and Wickham, J., 2011, Completion of the 2006 National Land Cover Database for the conterminous United States: Photogrammetric Engineering and Remote Sensing, v. 77, no. 9, p. 858-864.

Glatfelter, D.R., 1984, Techniques for estimating magnitude and frequency of floods in Indiana: U.S. Geological Survey Water-Resources Investigations Report 84-4134, 110 p.

Hannum, C.H., 1976, Techniques for estimating magnitude and frequency of floods in Kentucky: U.S. Geological Survey Water-Resources Investigations Report 76-62, 70 p.

Hayes, D.C., and Wiegand, U., 2006, Drainage areas of selected streams in Virginia: U.S. Geological Survey OpenFile Report 2006-1308, 51 p.

Hayes, D.C., and Young, R.L., 2005, Comparison of peak discharge and runoff characteristic estimates from the rational method to field observations for small basins in Central Virginia: U.S. Geological Survey Scientific Investigations Report 2005-5254, 44 p.

Helsel, D.R., and Hirsch, R.M., 2002, Statistical methods in water resources: U.S. Geological Survey Techniques of Water-Resources Investigations Report, book 4, chap. A3, $510 \mathrm{p}$.

Hirsch, R.M., Slack, J.R., and Smith, R.A., 1982, Techniques of trend analysis for monthly water quality data: Water Resources Research, v. 18, no. 1, p. 107-121.

Homer and others, 2004, Development of a 2001 National Landcover Database for the United States: Photogrammetric Engineering and Remote Sensing, v. 70, no. 9, p. 829-840. 
Interagency Advisory Committee on Water Data, 1982, Guidelines for determining flood flow frequency: Bulletin 17B of the Hydrology Subcommittee, Office of Water Data Coordination: U.S. Geological Survey, Reston, Va., Gilroy, E.J., personal communication to C. Hardison, 1974, as noted on page 1-3 of Appendix 1 and listed on page 8-1 of Appendix 8.

Jennings, M.E., and Benson, M.A., 1969, Frequency curves for annual flood series with some zero events or incomplete data: Water Resources Research, v. 5, no. 1, p. 276-280.

Kirby, W., 1980, Computer routines for probability distributions, random numbers, and related functions: U.S. Geological Survey Open-File Report 80-448, 61 p.

Klein, R.D., 1979, Urbanization and stream quality impairment: American Water Resources Association, Water Resources Bulletin, v. 15, no. 4, p. 948-963.

Krstolic, J.L., 2006, Drainage basin delineations for selected USGS streamflow-gaging stations in Virginia: U.S. Geological Survey Dataset, accessed September 23, 2013, at http://water.usgs.gov/GIS/metadata/usgswrd/XML/ ofr2006-1308_Drainage_Basin.xml.

Landers, M.N., Ankcorn, P.D., and McFadden, K.W., 2007, Watershed effects on streamflow quantity and quality in six watersheds of Gwinnett Count, Georgia: U.S. Geological Survey Scientific Investigations Report 2007-5132, 62 p., accessed September 23, 2013, at http://pubs.usgs.gov/ sir/2007/5132/.

Lane, E.W., and Lei, K., 1950, Stream flow variability: Transactions of the American Society of Civil Engineers, v. 115, p. 1084-1134.

Langbein, W.B., and Iseri, K.T., 1995, General introduction and hydrologic definitions, manual of hydrology —Part 1. General surface-water techniques: U.S. Geological Survey Water-Supply Paper 1541-A, 29 p. (Also available at http:// water.usgs.gov/wsc/glossary.html.)

Leopold, L.B., 1968, Hydrology for urban land planning-A guidebook on the hydrologic effects of urban land use: U.S. Geological Survey Circular 554, 18 p.

Lynch, D.D., 1987, Hydrologic conditions and trends in Shenandoah National Park, Virginia: U.S. Geological Survey Water-Resources Investigations Report 87-4131, 115 p.

Mallin, M.A., Williams, K.E., Esham, E.C., and Lowe, R.P., 2000, Effect of human development on bacteriological water quality in coastal watersheds: Ecological Applications, v. 10, no. 4, p. 1047-1056.

Miller, E.M., 1969, Floods in Virginia, magnitude and frequency: U.S. Geological Survey Open-File Report, 54 p.

Miller, E.M., 1978, Technique for estimating magnitude and frequency of floods in Virginia: U.S. Geological Survey Water-Resources Investigations Report 78-5, 83 p.
Mohler, E.H., Jr., and Hagan, G.F., 1981, Low flow of streams in Fairfax County, Virginia: U.S. Geological Survey OpenFile Report 81-63, 30 p.

Mosteller, F., and Tukey, J.W., 1977, Data analysis and regression-A second course in statistics: Reading, Mass., Addison-Wesley, $588 \mathrm{p}$.

Nuckels, E.H., 1970, Virginia streamflow data program analysis: U.S. Geological Survey Open-File Report, 54 p.

Paybins, K.S., 2008, Basin characteristics for selected streamflow-gaging stations in and near West Virginia: U.S. Geological Survey Open-File Report 2008-1087, 9 p. (Also available at $h t t p: / / p u b s . u s g s . g o v / o f / 2008 / 1087 /$.

PRISM Climate Group, Oregon State University, 2007, Mean annual precipitation from 1971 to 2000 and average monthly rainfall for January, February, and March, accessed May 5, 2008, at http://prism.oregonstate.edu/products/ matrix.phtml.

Rice, K.C., 2000, Effects of urban sprawl on the water resources of northern Virginia [PDF file-593 KB]: Federal Urban Sprawl Workshop, December 6-8, 2000, Harpers Ferry, W. Va.

Sall, J., 1990, Leverage plots for general linear hypotheses: The American Statistician, v. 44, no. 4, p. 308-315.

SAS Institute Inc., 2012, JMP 10 modeling and multivariate methods: Cary, N.C., SAS Institute, Inc., 703 p.

Speer, P.R., and Gamble, C.R., 1964a, Magnitude and frequency of floods in the United States-Part 2A, South Atlantic slope basins, James River to Savannah River: U.S. Geological Survey Water-Supply Paper 1673, 329 p.

Speer, P.R., and Gamble, C.R., 1964b, Magnitude and frequency of floods in the United States-Part 3B, Cumberland and Tennessee River basins: U.S. Geological Survey Water-Supply Paper 1676, $340 \mathrm{p}$.

Speer, P.R., and Gamble, C.R., 1965, Magnitude and frequency of floods in the United States-Part 3A, Ohio River basin except Cumberland and Tennessee River basins: U.S. Geological Survey Water-Supply Paper 1675, 630 p.

Trainer, F.W., and Watkins, F.A., Jr., 1975, Geohydrologic reconnaissance of the upper Potomac River basin: U.S. Geological Survey Water-Supply Paper 2035, 68 p.

Wetzel, K.L., and Bettandorff, J.M., 1986, Techniques for estimating streamflow characteristics in the eastern and interior coal provinces of the United States: U.S. Geological Survey Water-Supply Paper 2276, 80 p.

Yang, L., Huang, C., Homer, C.G., Wylie, B.K., and Coan, M.J., 2003, An approach for mapping large-area impervious surfaces - Synergistic use of Landsat-7 ETM+ and high spatial resolution imagery: Canadian Journal of Remote Sensing, v. 29, no. 2, p. 230-240. 
Table 1. Drainage basins used to estimate Virginia urban peak-flow discharge per square mile.

$\left[\mathrm{mi}^{2}\right.$, square miles; \%, percent $]$

\begin{tabular}{|c|c|c|c|}
\hline Station number & Station name & $\begin{array}{l}\text { Basin drainage } \\
\text { area }\left(\mathrm{mi}^{2}\right)\end{array}$ & $\begin{array}{c}\text { Basin urban } \\
\text { area }(\%)\end{array}$ \\
\hline 01613900 & Hogue Creek at Route 614 near Hayfield, Va. & 15.95 & 10.59 \\
\hline 01615000 & Opequon Creek above Route 7 near Berryville, Va. & 58.16 & 18.78 \\
\hline 01616000 & Abrams Creek above Route 659 near Winchester, Va. & 17.00 & 55.88 \\
\hline 01621450 & Blacks Run tributary 1 at Route 11 near Harrisonburg, Va. & 0.67 & 15.41 \\
\hline 01623000 & Bell Creek at St. Pauls Chapel, near Staunton, Va. & 0.67 & 14.05 \\
\hline 01623500 & Bell Creek along Route 612 near Staunton, Va. & 3.85 & 18.99 \\
\hline 01624000 & Bell Creek at Route 732 at Franks Mill near Staunton, Va. & 9.81 & 16.94 \\
\hline 01624800 & Christians Creek at Route 794 near Fishersville, Va. & 73.03 & 15.15 \\
\hline 01625000 & Middle River at Route 769 near Grottoes, Va. & 372.73 & 13.51 \\
\hline 01626000 & South River at Route 664 near Waynesboro, Va. & 126.92 & 11.22 \\
\hline 01626500 & South River (at Basic City) at Lyndhurst Road at Waynesboro, Va. & 133.49 & 13.66 \\
\hline 01626850 & South River at Hopeman Parkway near Dooms, Va. & 147.77 & 15.60 \\
\hline 01627500 & South River at Route 778 at Harriston, Va. & 211.65 & 14.84 \\
\hline 01628500 & South Fork Shenandoah River below Lower Lewis Run near Lynnwood, Va. & $1,079.32$ & 11.65 \\
\hline 01629500 & South Fork Shenandoah River at Route 211 near Luray, Va. & $1,372.27$ & 10.97 \\
\hline 01631000 & South Fork Shenandoah River below Route 619 at Front Royal, Va. & $1,634.30$ & 10.55 \\
\hline 01636210 & Happy Creek at Kerfoot Avenue at Front Royal, Va. & 14.01 & 10.71 \\
\hline 0163626650 & Manassas Run at Route 645 near Front Royal, Va. & 11.22 & 15.52 \\
\hline 01638350 & South Fork Catoctin Creek at Route 698 near Waterford, Va. & 31.62 & 10.48 \\
\hline 01643805 & North Fork Goose Creek at Route 729 near Lincoln, Va. & 38.12 & 11.39 \\
\hline 01644280 & Broad Run at Route 7 near Leesburg, Va. & 76.13 & 38.70 \\
\hline 01644290 & Stave Run at Parking Lot Road at Reston, Va. & 0.07 & 91.40 \\
\hline 01644291 & Stave Run below Parking Lot Road near Reston, Va. & 0.08 & 91.43 \\
\hline 01644295 & Smilax Branch at Dulles Airport Road at Reston, Va. & 0.33 & 75.03 \\
\hline 01644300 & Sugarland Run at Route 606 at Herndon, Va. & 3.39 & 81.35 \\
\hline 01645700 & Difficult Run at Route 665 near Fairfax, Va. & 4.36 & 47.91 \\
\hline 01645750 & South Fork Little Difficult Run at Fox Mill Road near Fairfax, Va. & 1.58 & 24.68 \\
\hline 01645784 & Snakeden Branch at Soapstone Drive at Reston, Va. & 0.79 & 62.38 \\
\hline 01645800 & Piney Branch above railroad at Vienna, Va. & 0.27 & 77.69 \\
\hline 01645900 & Colvin Run at Hunter Mill Road at Reston (near Herndon), Va. & 5.04 & 50.81 \\
\hline 01645975 & Rocky Run at Towlston Road near Great Falls, Va. & 3.19 & 29.52 \\
\hline 01646000 & Difficult Run below Route 193 near Great Falls, Va. & 57.83 & 35.77 \\
\hline 01646200 & Scott Run at Old Georgetown Pike near McLean, Va. & 4.67 & 61.73 \\
\hline 01646600 & Pimmit Run at Great Falls Road near Falls Church, Va. & 2.88 & 74.53 \\
\hline 01646700 & Pimmit Run below Kirby Road at Arlington, Va. & 8.26 & 67.85 \\
\hline 01646750 & Little Pimmit Run tributary above Little Falls Road at Arlington, Va. & 0.43 & 90.74 \\
\hline 01646800 & Little Pimmit Run at Route 689 at Arlington, Va. & 2.31 & 64.33 \\
\hline 01652400 & Long Branch at South Carlyn Springs Road at Arlington, Va. & 0.94 & 91.00 \\
\hline 01652430 & Doctors Run at 8th Street at Arlington, Va. & 0.93 & 91.80 \\
\hline 01652470 & Lucky Run at Dinwiddie Street at Arlington, Va. & 1.30 & 93.64 \\
\hline 01652500 & Fourmile Run at Shirlington Road at Alexandria, Va. & 12.59 & 86.50 \\
\hline 01652600 & Holmes Run at Route 50 at Merrifield, Va. & 2.73 & 71.83 \\
\hline
\end{tabular}


Table 1. Drainage basins used to estimate Virginia urban peak-flow discharge per square mile.-Continued $\left[\mathrm{mi}^{2}\right.$, square miles; $\%$, percent $]$

\begin{tabular}{|c|c|c|c|}
\hline Station number & Station name & $\begin{array}{c}\text { Basin drainage } \\
\text { area }\left(\mathrm{mi}^{2}\right)\end{array}$ & $\begin{array}{c}\text { Basin urban } \\
\text { area }(\%)\end{array}$ \\
\hline 01652610 & Holmes Run at Sleepy Hollow Road near Annandale, Va. & 7.11 & 63.05 \\
\hline 01652620 & Tripps Run above South Washington Street at Falls Church, Va. & 1.91 & 67.64 \\
\hline 01652645 & Tripps Run tributary at Holmes Run Road near Falls Church, Va. & 0.51 & 70.99 \\
\hline 01652650 & Tripps Run at Sleepy Hollow Road near Falls Church, Va. & 4.63 & 71.48 \\
\hline 01652710 & Backlick Run at Leesville Boulevard at Springfield, Va. & 2.08 & 63.68 \\
\hline 01652810 & Turkeycock Run at Shirley Route at Alexandria, Va. & 2.28 & 64.51 \\
\hline 01652910 & Backlick Run below South Van Dorn Street at Alexandria, Va. & 13.48 & 73.91 \\
\hline 01653000 & Cameron Run below railroad bridge at Alexandria, Va. & 33.86 & 70.21 \\
\hline 01653210 & Pike Branch at Route 611 at Alexandria, Va. & 2.59 & 78.74 \\
\hline 01653447 & Penn Daw outfall at Huntington Avenue at Alexandria, Va. & 0.79 & 81.53 \\
\hline 01653900 & Accotink Creek at Pickett Street at Fairfax, Va. & 6.86 & 73.88 \\
\hline 01653950 & Long Branch at Lee Route at Vienna, Va. & 1.21 & 71.38 \\
\hline 01654000 & Accotink Creek above Route 620 near Annandale, Va. & 23.87 & 62.22 \\
\hline 01654500 & Long Branch (Little Run) at Route 620 near Annandale, Va. & 3.72 & 59.32 \\
\hline 01655000 & Accotink Creek at Army Engineer Road near Accotink Station, Va. & 37.07 & 61.81 \\
\hline 01655310 & Rabbit Branch at Guinea Road near Burke, Va. & 3.82 & 64.03 \\
\hline 01655350 & Pohick Creek at Hooes Road near Springfield, Va. & 15.17 & 64.87 \\
\hline 01655370 & Middle Run at Route 640 near Lorton, Va. & 3.64 & 68.32 \\
\hline 01655380 & South Run at Hooes Road near Lorton, Va. & 6.30 & 30.47 \\
\hline 01655390 & Pohick Creek at Lorton Road at Lorton, Va. & 31.26 & 54.24 \\
\hline 01656800 & Cub Run at Route 50 near Chantilly, Va. & 7.75 & 51.67 \\
\hline 01656960 & Cub Run at Route 658 near Bull Run, Va. & 49.74 & 52.27 \\
\hline 01657000 & Bull Run at Route 616 near Manassas, Va. & 145.98 & 29.10 \\
\hline 01657415 & Bull Run above Yates Ford near Clifton, Va. & 184.70 & 29.55 \\
\hline 01657500 & Occoquan River (Creek) near Occoquan (site now in Occoquan Reservoir), Va & 570.14 & 15.85 \\
\hline 01657655 & Hooes Run above Route 641 near Occoquan, Va. & 3.92 & 45.08 \\
\hline 01657800 & Giles Run at Route 1 near Woodbridge, Va. & 4.52 & 41.39 \\
\hline 01667600 & Cedar Run tributary at Route 522 near Culpeper, Va. & 0.67 & 12.35 \\
\hline 01673500 & Totopotomoy Creek at Route 301 near Atlee, Va. & 5.77 & 31.50 \\
\hline 01673550 & Totopotomoy Creek at Route 606 near Studley, Va. & 25.53 & 14.95 \\
\hline 02019400 & Mill (Looney Mill) Creek at Route 636 near Buchanan, Va. & 29.30 & 13.09 \\
\hline 02027700 & Buffalo River tributary at Route 60 near Amherst, Va. & 0.45 & 13.56 \\
\hline 02030800 & Stockton Creek at Route 6 near Afton, Va. & 2.70 & 17.31 \\
\hline 02031000 & Mechums River at Route 614 near White Hall (Ivy), Va. & 95.27 & 11.54 \\
\hline 02032700 & Schenks Branch above Route 250 at Charlottesville, Va. & 1.39 & 95.96 \\
\hline 02033500 & Rivanna River below Moores Creek near Charlottesville, Va. & 503.28 & 12.41 \\
\hline 02034000 & Rivanna River at Route 15 at Palmyra, Va. & 662.77 & 11.83 \\
\hline 02034050 & Hunters Branch at Route 15 near Palmyra, Va. & 1.59 & 13.74 \\
\hline 02037800 & Falling Creek at Route 653 near Midlothian, Va. & 18.16 & 66.61 \\
\hline 02038000 & Falling Creek at Route 651 near Chesterfield, Va. & 33.10 & 58.19 \\
\hline 02038500 & Falling Creek at Hopkins Road near Drewrys Bluff, Va. & 53.35 & 59.25 \\
\hline 02042000 & Swift Creek at Bradley Bridge Road near Chester, Va. & 140.15 & 16.99 \\
\hline 02042287 & Chickahominy River at Route 301 near Atlee, Va. & 62.15 & 23.70 \\
\hline
\end{tabular}


Table 1. Drainage basins used to estimate Virginia urban peak-flow discharge per square mile.-Continued

$\left[\mathrm{mi}^{2}\right.$, square miles; \%, percent $]$

\begin{tabular}{|c|c|c|c|}
\hline Station number & Station name & $\begin{array}{c}\text { Basin drainage } \\
\text { area }\left(\mathrm{mi}^{2}\right)\end{array}$ & $\begin{array}{c}\text { Basin urban } \\
\text { area }(\%)\end{array}$ \\
\hline 02042426 & Upham Brook at Wilkinson Road near Richmond, Va. & 37.45 & 66.86 \\
\hline 02042500 & Chickahominy River at Route 618 near Providence Forge, Va. & 251.47 & 24.49 \\
\hline 02042780 & West Branch Long Hill Swamp at Route 612 near Lightfoot, Va. & 2.47 & 14.22 \\
\hline 02044400 & Hurricane Branch at Route 40 at Blackstone, Va. & 1.61 & 22.16 \\
\hline 02055000 & Roanoke River at Walnut Street at Roanoke, Va. & 383.92 & 18.65 \\
\hline 02055100 & Tinker Creek below railroad bridge near Daleville, Va. & 11.69 & 14.73 \\
\hline 02056000 & Roanoke River below powerplant at Niagara, Va. & 509.45 & 23.56 \\
\hline 02056650 & Back Creek at Route 660 near Dundee, Va. & 55.81 & 18.67 \\
\hline 02057500 & Roanoke River near Toshes, Va. & $1,017.01$ & 15.21 \\
\hline 02057700 & Powder Mill Creek at Route 220 at Rocky Mount, Va. & 0.78 & 71.86 \\
\hline 02059000 & Roanoke River at Route 1109 near Gretna, Va. & $1,418.33$ & 12.18 \\
\hline 02059450 & South Fork Goose Creek at Route 607 at Montvale, Va. & 10.97 & 10.81 \\
\hline 02060500 & Roanoke (Staunton) River at Route 29 (Alternate) at Altavista, Va. & $1,781.97$ & 10.91 \\
\hline 02061150 & Chestnut Branch near Forest at Goode, Va. & 1.54 & 14.37 \\
\hline 02062500 & Roanoke (Staunton) River above Route 501 at Brookneal, Va. & $2,403.72$ & 10.22 \\
\hline 02076400 & Whitethorn Creek tributary at Route 29 at Gretna, Va. & 2.02 & 19.11 \\
\hline 02076500 & Georges Creek at Route 40 near Gretna, Va. & 9.18 & 15.84 \\
\hline 03165200 & Mill Creek tributary at Route 58 at Galax, Va. & 1.07 & 33.69 \\
\hline 03167300 & Mira Fork tributary at Route 221 near Dugspur, Va. & 0.66 & 10.01 \\
\hline 03167700 & Beaverdam Creek at Route 1009 at Hillsville, Va. & 4.47 & 20.10 \\
\hline 03177700 & Bluestone River above wastewater outfall at Bluefield, Va. & 39.75 & 26.83 \\
\hline 03177710 & Bluestone River at Route 717 at Falls Mills, Va. & 44.27 & 25.75 \\
\hline 03474700 & Hutton Creek at Route 11 near Chilhowie, Va. & 8.20 & 16.00 \\
\hline 03474800 & Hall Creek at Route 11 near Glade Spring, Va. & 7.83 & 10.15 \\
\hline 03475600 & Cedar Creek at Route 11 near Meadowview, Va. & 3.42 & 20.51 \\
\hline 03475700 & Spring Creek at Route 11 near Abingdon, Va. & 2.78 & 10.06 \\
\hline 03478400 & Beaver Creek at Route 1405 at (near) Bristol, Va. & 26.94 & 14.42 \\
\hline 03524500 & Guest River at Route 72 at Coeburn, Va. & 87.16 & 15.03 \\
\hline 03525800 & Copper Creek tributary 1 at Route 58 (Alternate) near Dickensonville, Va. & 0.68 & 16.53 \\
\hline 03530000 & South Fork Powell River at Route 23 at Big Stone Gap, Va. & 39.75 & 12.06 \\
\hline
\end{tabular}


Table 2. Parameters for regression equations used for estimating Virginia urban peak-flow discharge per square mile.

[DA, basin drainage area in square miles; URBAN, basin urban area in percent]

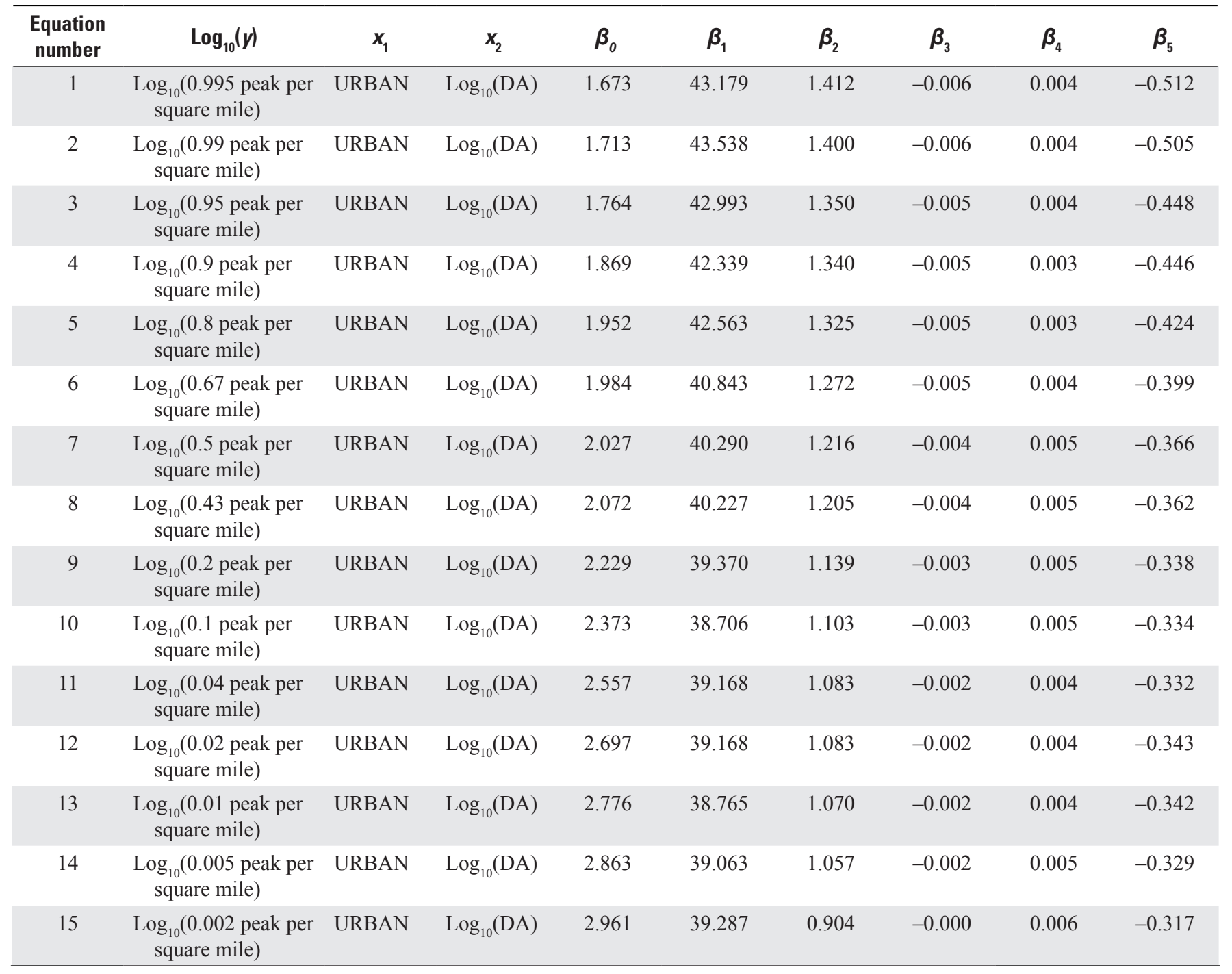


Table 3. Regression equation prediction expressions for estimating Virginia urban peak-flow discharge per square mile.

[DA, basin drainage area in square miles; AEP, annual exceedance probability; URBAN, basin urban area in percent]

\begin{tabular}{|c|c|c|c|c|}
\hline $\begin{array}{l}\text { Equation } \\
\text { number }\end{array}$ & Regression equation prediction expression & R-square & $\begin{array}{l}\text { Root mean } \\
\text { square error }\end{array}$ & Observations \\
\hline 1 & $\begin{array}{l}\log _{10}(0.995 \text { AEP peak per square mile })=1.673+(\mathrm{URBAN}-43.179) \times \\
\quad\left(\left(\log _{10}(\mathrm{DA})-1.412\right) \times-0.00637\right)+0.00372 \times \mathrm{URBAN}+-0.512 \times \\
\quad \log _{10}(\mathrm{DA})\end{array}$ & 0.84 & 0.26 & 69 \\
\hline 2 & $\begin{array}{l}\log _{10}(0.99 \text { AEP peak per square mile })=1.713+(\text { URBAN }-43.538) \times \\
\quad\left(\left(\log _{10}(\text { DA })-1.400\right) \times-0.00626\right)+0.00359 \times \text { URBAN }+-0.505 \times \\
\quad \log _{10}(\text { DA })\end{array}$ & 0.84 & 0.26 & 70 \\
\hline 3 & $\begin{array}{l}\log _{10}(0.95 \text { AEP peak per square mile })=1.764+(\text { URBAN }-42.993) \times \\
\quad\left(\left(\log _{10}(\text { DA })-1.350\right) \times-0.00518\right)+0.00391 \times \text { URBAN }+-0.448 \times \\
\quad \log _{10}(\text { DA })\end{array}$ & 0.84 & 0.23 & 80 \\
\hline 4 & $\begin{array}{l}\log _{10}(0.9 \text { AEP peak per square mile })=1.869+(\text { URBAN }-42.339) \times \\
\quad\left(\left(\log _{10}(\text { DA })-1.340\right) \times-0.00523\right)+0.00323 \times \text { URBAN }+-0.446 \times \\
\quad \log _{10}(\text { DA })\end{array}$ & 0.83 & 0.23 & 85 \\
\hline 5 & $\begin{array}{l}\log _{10}(0.8 \text { AEP peak per square mile })=1.952+(\text { URBAN }-42.563) \times \\
\quad\left(\left(\log _{10}(\text { DA })-1.325\right) \times-0.00459\right)+0.00336 \times \text { URBAN }+-0.424 \times \\
\quad \log _{10}(\text { DA })\end{array}$ & 0.83 & 0.23 & 89 \\
\hline 6 & $\begin{array}{l}\log _{10}(0.67 \text { AEP peak per square mile })=1.984+(\text { URBAN }-40.843) \times \\
\quad\left(\left(\log _{10}(\text { DA })-1.272\right) \times-0.00479\right)+0.00402 \times \text { URBAN }+-0.399 \times \\
\quad \log _{10}(\text { DA })\end{array}$ & 0.82 & 0.23 & 97 \\
\hline 7 & $\begin{array}{l}\log _{10}(0.5 \text { AEP peak per square mile })=2.027+(\text { URBAN }-40.290) \times \\
\quad\left(\left(\log _{10}(\text { DA })-1.216\right) \times-0.00414\right)+0.00468 \times \text { URBAN }+-0.366 \times \\
\quad \log _{10}(\text { DA })\end{array}$ & 0.81 & 0.23 & 103 \\
\hline 8 & $\begin{array}{l}\log _{10}(0.43 \text { AEP peak per square mile })=2.072+(\text { URBAN }-40.227) \times \\
\quad\left(\left(\log _{10}(\text { DA })-1.205\right) \times-0.00403\right)+0.00465 \times \text { URBAN }+-0.362 \times \\
\quad \log _{10}(\text { DA })\end{array}$ & 0.81 & 0.23 & 104 \\
\hline 9 & $\begin{array}{l}\log _{10}(0.2 \text { AEP peak per square mile })=2.229+(\text { URBAN }-39.370) \times \\
\quad\left(\left(\log _{10}(\text { DA })-1.139\right) \times-0.00346\right)+0.00487 \times \text { URBAN }+-0.338 \times \\
\quad \log _{10}(\text { DA })\end{array}$ & 0.76 & 0.24 & 110 \\
\hline 10 & $\begin{array}{l}\log _{10}(0.1 \text { AEP peak per square mile })=2.373+(\text { URBAN }-38.706) \times \\
\quad\left(\left(\log _{10}(\text { DA })-1.103\right) \times-0.00313\right)+0.00470 \times \text { URBAN }+-0.334 \times \\
\quad \log _{10}(\text { DA })\end{array}$ & 0.74 & 0.25 & 113 \\
\hline 11 & $\begin{array}{l}\log _{10}(0.04 \text { AEP peak per square mile })=2.557+(\mathrm{URBAN}-39.168) \times \\
\quad\left(\left(\log _{10}(\mathrm{DA})-1.083\right) \times-0.00224\right)+0.00434 \times \mathrm{URBAN}+-0.332 \times \\
\quad \log _{10}(\mathrm{DA})\end{array}$ & 0.69 & 0.28 & 114 \\
\hline 12 & $\begin{array}{l}\log _{10}(0.02 \text { AEP peak per square mile })=2.697+(\text { URBAN }-39.168) \times \\
\quad\left(\left(\log _{10}(\text { DA })-1.083\right) \times-0.00219\right)+0.00390 \times \text { URBAN }+-0.343 \times \\
\quad \log _{10}(\text { DA })\end{array}$ & 0.65 & 0.31 & 114 \\
\hline 13 & $\begin{array}{l}\log _{10}(0.01 \text { AEP peak per square mile })=2.776+(\mathrm{URBAN}-38.765) \times \\
\quad\left(\left(\log _{10}(\mathrm{DA})-1.070\right) \times-0.00242\right)+0.00434 \times \mathrm{URBAN}+-0.342 \times \\
\quad \log _{10}(\mathrm{DA})\end{array}$ & 0.57 & 0.37 & 110 \\
\hline 14 & $\begin{array}{l}\log _{10}(0.005 \text { AEP peak per square mile })=2.863+(\text { URBAN }-39.063) \times \\
\quad\left(\left(\log _{10}(\text { DA })-1.057\right) \times-0.00223\right)+0.00465 \times \text { URBAN }+-0.329 \times \\
\quad \log _{10}(\text { DA })\end{array}$ & 0.55 & 0.38 & 105 \\
\hline 15 & $\begin{array}{l}\log _{10}(0.002 \text { AEP peak per square mile })=2.961+(\text { URBAN }-39.287) \times \\
\left(\left(\log _{10}(\text { DA })-0.904\right) \times-0.00049\right)+0.00636 \times \text { URBAN }+-0.317 \times \\
\log _{10}(\text { DA })\end{array}$ & 0.44 & 0.46 & 65 \\
\hline
\end{tabular}


For additional information regarding this publication, contact:

Director

USGS Virginia Water Science Center

1730 East Parham Road

Richmond, Virginia 23228

email: dc_va@usgs.gov

Or visit the USGS Virginia Water Science

Center Web site at:

http://va.water.usgs.gov

Prepared by:

USGS Science Publishing Network

Raleigh Publishing Service Center

3916 Sunset Ridge Road

Raleigh, NC 27607 

